FERNANDO BERROJALBIZ

INSTITUTO DE INVESTIGACIONES HISTÓRICAS, UNAM

\title{
Arte rupestre y paisaje simbólico mesoamericano en el norte de Durango
}

$\mathrm{E}$ L ARTE RUPESTRE DE LAS CULTURAS mesoamericanas, salvo algunas excepciones, no ha atraído la misma atención de los investigadores que otras formas de expresión como la pintura mural, la escultura o la cerámica, por poner unos pocos ejemplos de las artes más tratadas en los estudios de las culturas prehispánicas.

Por lo anterior, en innumerables ocasiones se ha dejado de estudiar una fuente riquísima de información para adentrarse no sólo en el pensamiento y en los sistemas simbólicos de muchas culturas, sino también en otros de sus ámbitos, como la concepción del espacio, los límites territoriales, la organización social, la distribución geográfica y la filiación cultural.

Afortunadamente, a partir de la última década del siglo pasado el panorama está cambiando y los estudios de arte rupestre no sólo de culturas cazadoras, recolectoras y pescadoras, sino de todo tipo de sociedades, han empezado a proliferar.

En los territorios de Durango y Zacatecas, los estudios sobre arte rupestre han sido muy escasos, a pesar de que en los pioneros estudios de arqueología del primer tercio del siglo XIX se tuvieran en cuenta estas manifestaciones. ${ }^{I}$ Esto es

I. Carl de Berghes, Descripción de las ruinas de asentamientos aztecas durante su migración al Valle de México, a través del actual Estado Libre de Zacatecas (I855), Achim Lelgemann (traducción, estudio introductorio y notas), Zacatecas, Gobierno del Estado de Zacatecas/Universidad Autónoma de Zacatecas/Centro Bancario del Estado de Zacatecas (Joyas Bibliográficas Zacatecanas II), 1996. 
un eco de lo que sucedió en cuanto a la investigación arqueológica en general, la cual, después de un brillante comienzo en el siglo xIx, durante el xx ha sido escasa en comparación con otras áreas, como la de la cultura maya.

Esta falta de estudios se hizo sentir en las expresiones rupestres de todo tipo de sociedades, que han dejado una vastísima obra en estos territorios. Sin embargo, es sorprendente que, a pesar de que los estudios arqueológicos del siglo xx se centraron en la cultura chalchihuiteña, de tradición mesoamericana, sobre todo por parte del equipo de estadounidenses encabezado por J. Charles Kelley, no se haya considerado o no se haya querido ver el arte rupestre de esta cultura. ${ }^{2}$

En la última década del siglo xx, el Proyecto Hervideros, del Instituto de Investigaciones Estéticas de la Universidad Nacional Autónoma de México, empezó a considerar la gran importancia del arte rupestre de la cultura chalchihuiteña e inició los estudios rigurosos de este arte en los territorios duranguenses. ${ }^{3}$

2. Este equipo de investigación, después de más de 20 años de trabajo y de ocuparse de un territorio enorme en Durango y Zacatecas, ha estudiado uno de los dos marcadores que se encuentran en el sitio de Cerro Chapín en Zacatecas (J. Charles Kelley y Ellen Abbott Kelley, "The Archaeoastronomical System in the Río Colorado Chalchihuites Polity, Zacatecas: An Interpretation of the Chapín I Pecked Cross Circle", en Michael S. Foster y Shirley Gorenstein (comps.), Greater Mesoamerica, Salt Lake City, The University of Utah Press, 200o). La misión belga que estuvo trabajando en el área alrededor de Huejuquilla el Alto, Jalisco, realizó el registro de dos sitios de arte rupestre, véase Françoise Fauconnier y Paulina Faba, "Las Adjuntas: arte rupestre chalchihuiteño y cosmovisión huichola”, en Carlo Bonfiglioli et al., Las vías del Noroeste II: hacia una perspectiva sistémica de una macrorregión indígena americana, México, Universidad Nacional Autónoma de México-Instituto de Investigaciones Antropológicas (en prensa); Nadine Orloff, "Découverte d'un site à gravures rupestres dans la Sierra del Nayar (Mexique)", Journal de la Société des Américanistes, París, Musée de l'Homme, t. LXVIII, I982, pp. 7-26. Fauconnier está realizando su tesis doctoral en la Universidad Libre de Bruselas sobre uno de estos sitios. En Huejuquilla el Alto se creó un museo, el Comunitario Tatuutsima, en el cual las imágenes de arte rupestre tienen un lugar importante en la sustentación del discurso sobre la cultura chalchihuiteña de la región (Marie-Areti Hers, "El museo Tatuutsima de Huejuquilla el Alto, Jalisco", en Primer Encuentro del Seminario Permanente de Estudios de La Gran Chichimeca, Universidad de Guadalajara (en prensa). Es necesario señalar la labor de localización y los primeros intentos de estudio de sitios de arte rupestre realizados por unos duranguenses aficionados a la arqueología (Jesús F. Lazalde, Durango indígena. Panorama cultural de un pueblo prehispánico en el Noroeste de México, Gómez Palacio, Durango, Impresiones Gráficas México, 1987; Jaime Ganot y Alejandro Peshard, Aztatlán. Apuntes para la historia y la arqueología de Durango, Durango, Gobierno del Estado de Durango-Secretaría de Educación, Cultura y Deporte, 1997).

3. Marta Forcano i Aparicio, "Las pinturas rupestres de Potrero de Cháidez, Durango", en Marie-Areti Hers et al. (eds.), Nómadas y sedentarios en el Norte de México, homenaje a Beatriz 
Dentro de este proyecto realicé el estudio del valle del alto ríos Ramos, al norte de Durango, que conformó mi tesis doctoral. En esta investigación hice un primer análisis del arte rupestre chalchihuiteño que se encuentra en este valle, pero era necesario ampliar ese estudio inicial. El propósito del presente artículo es acercarse al paisaje simbólico de ese territorio, pero teniendo en cuenta que el arte rupestre tiene el papel de eje articulador de dicho paisaje. Además del arte rupestre, he encontrado elementos de aproximación al paisaje simbólico en otros tres aspectos de los vestigios arqueológicos de los chalchihuiteños, a saber: el patrón de asentamiento, la arquitectura y la escultura. Voy a conjugar la información de todos estos ámbitos para proponer una explicación de la concepción simbólica del espacio que tenían los habitantes del alto río Ramos en la época chalchihuiteña, siguiendo el hilo conductor de sus expresiones en las rocas.

Para comprender mejor los complejos significados de estas expresiones y el paisaje simbólico al que pertenecen es necesario considerar en primer lugar algunas ideas sobre la historia de los chalchihuiteños en Durango y más concretamente en el valle del alto río Ramos.

\section{Los chalchihuiteños en los territorios de Durango}

Hacia el año 600 d.C. aproximadamente, en la cultura chalchihuiteña, de carácter mesoamericano, se están produciendo cambios importantes, apreciables en Jalisco y Zacatecas, que se traducen, entre otras cosas, en la aparición de motivos figurativos en las distintas expresiones de esa cultura, a diferencia de la exclusividad de motivos geométricos plasmados hasta ese momento.

La ocupación chalchihuiteña de Durango se produce a partir de esos cambios en el año 600 d.C., en la fase Ayala-Las Joyas, desde los territorios del oeste y norte de Zacatecas y extremo sur de Durango (fig. I).

Braniff, México, Universidad Nacional Autónoma de México-Instituto de Investigaciones Antropológicas, Estéticas e Históricas, 2000, pp. 489-510; Marta Forcano, El arte rupestre del alto Nazas, Durango, 1997, ms.; Marie-Areti Hers, "La música amorosa de Kokopelli y el erotismo sagrado en los confines mesoamericanos", en Arnulfo Herrera (comp.), XXIII Coloquio Internacional de Historia del Arte. Amor y desamor en las artes, México, Universidad Nacional Autónoma de México-Instituto de Investigaciones Estéticas, 200I; Fernando Berrojalbiz et al., "Arte rupestre y paisaje cultural: pasado, presente y futuro del sitio El Salto del Perro, Durango", en Actas del Primer Simposio Nacional sobre Representaciones Rupestres, México, noviembre de 2005 (en prensa). 


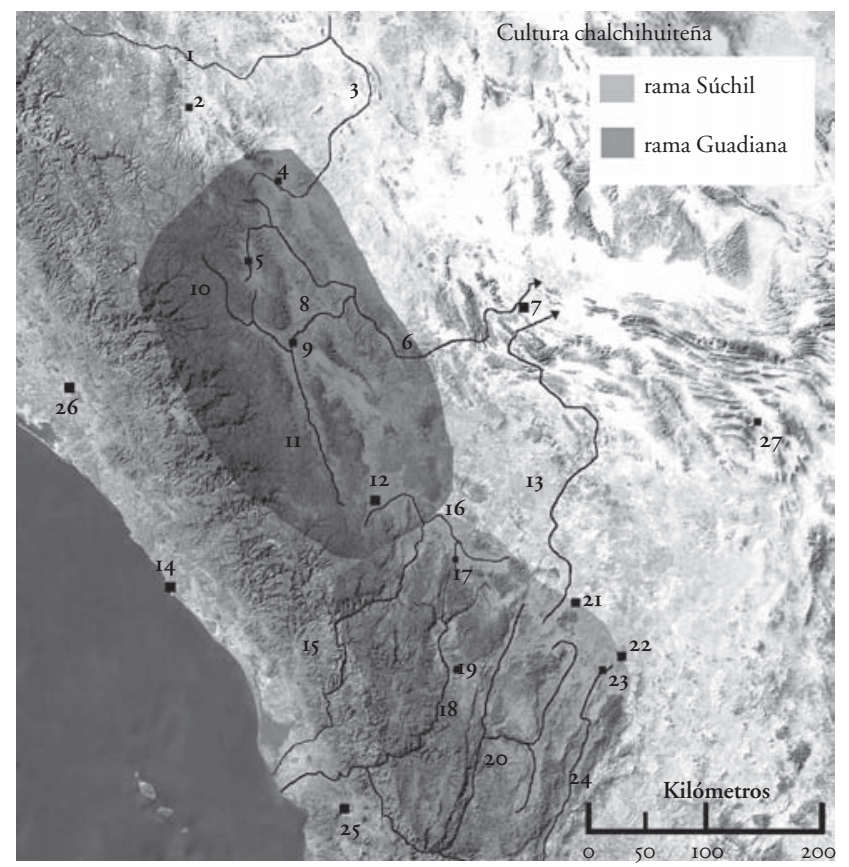

\author{
I. Río Conchos \\ 2. Valle de Balleza \\ 3 Río Florido \\ 4. Loma San Gabriel \\ 5. Zape \\ 6. Río Sextín-Nazas \\ 7. Torreón \\ 8. Río Ramos \\ 9. Valle del alto río Ramos \\ Io. Río Tepehuanes \\ II. Río Santiago \\ I2. Durango \\ I3. Río Aguanaval \\ I4. Mazatlán \\ I5. Río Mezquital-San Pedro \\ I6. Río Súchil \\ 17. Alta Vista \\ I8. Río Chapalagana \\ 19. Cerro del Huistle \\ 20. Río Bolanos \\ 2I. Fresnillo \\ 22. Zacatecas \\ 23. La Quemada \\ 24. Río Malpaso-Juchipila \\ 25. Tepic \\ 26. Culiacán \\ 27. Concepción del Oro
}

I. Mapa de los territorios de la cultura chalchihuiteña en las diferentes etapas de su desarrollo y de la ubicación del valle del alto río Ramos. Realización del autor.

Se trata de una gran gesta colonizadora que abarca no sólo los valles orientales, sino también la parte alta de la Sierra Madre Occidental y la zona de las Quebradas hacia Sinaloa. Esta acción de enormes proporciones y espacios, que se llevó a cabo en la misma época y que refleja una gran unidad en todas sus manifestaciones culturales, indica que existía una programación, acciones concertadas entre distintos grupos y por lo tanto una organización que abarcaba un gran número de personas y las unificaba con los mismos fines.

Como resultado de estas acciones surgieron sitios, con carácter de centros regionales, de más de 30 hectáreas. Además de estos centros hubo sitios de diversos tipos, con diferentes rangos, tamaños y funciones. No obstante, el carácter estratégico y el de defensa fueron primordiales en los asentamientos de esta época ante la amenaza de grupos cazadores, recolectores, pescadores y las guerras entre comunidades chalchihuiteñas, imbuidas probablemente de la mística de la "guerra florida". ${ }^{4}$ 
Un aspecto que destaca de los sitios grandes con carácter de centros regionales construidos en Durango es que en los vestigios que quedan de su arquitectura no se observan indicios de una diferencia entre grupos sociales. En esta primera etapa chalchihuiteña en Durango, de gran impulso colonizador y cultural sobre vastos territorios, prevalece la tendencia a que se realicen estas alianzas entre numerosos grupos que dan lugar a grandes asentamientos.

También existían relaciones entre las poblaciones duranguenses con las culturas de Sinaloa y Nayarit, que se evidencian sobre todo en la cerámica y en las conchas, y fuertes conexiones con culturas del suroeste de Estados Unidos, principalmente en el ámbito simbólico, que se reflejan en la iconografía de distintas expresiones. ${ }^{5}$

La siguiente fase, Tunal-Calera (900/100o d.C.-I300 d.C.), está marcada por la desaparición de la ocupación chalchihuiteña al sur, en las áreas del norte de Jalisco y Zacatecas, donde se había originado la cultura chalchihuiteña, quedando únicamente la ocupación en los territorios duranguenses.

Por otra parte, el contacto con culturas del suroeste de Estados Unidos continúan, teniendo como mayor exponente la aparición de sitios del tipo "casas en acantilado".

Los cambios anteriores apuntan también a que la organización sociopolítica y el ordenamiento del territorio sufrió reajustes y cambios. En la segunda etapa ya no hay una empresa colonizadora y se da un quiebre en las tradiciones culturales. La tendencia es a asentamientos más pequeños con menor población, una ocupación más dispersa y un desarrollo cultural propio de los sitios duranguenses.

\section{La ocupación chalchibuiteña del alto río Ramos}

El valle del alto río Ramos se halla en el noroeste de Durango y pertenece a la cuenca alta del río Nazas. Se encuentra en el límite noreste del valle de Santiago Papasquiaro, en la vertiente oriental de la Sierra Madre Occidental. Al norte de

Braniff (comp.), La gran Chichimeca. El lugar de las rocas secas, México/Milán, Consejo Nacional para la Cultura y las Artes/Jaca Book, 200I; "La sierra tepehuana: imágenes y discordancias sobre su pasado prehispánico", en Chantal Cramaussel (comp.), Asentamientos y movimientos de población en la sierra tepehuana desde la prehistoria hasta nuestros días. Simposio Internacional, Santa María Ocotán, 2000, Zamora, El Colegio de Michoacán (en prensa).

5. Hers, "La música amorosa...”, op. cit. 
este valle de Santiago se produce la confluencia de los ríos Santiago y Tepehuanes, a partir de la cual el río toma el nombre de Ramos y se inicia un pequeño valle que termina $8 \mathrm{~km}$ al norte, al entrar el río en el cañón de Pichagua (fig. 2).

En la primera etapa, Ayala-Las Joyas (600 d.C.-900/ıooo d.C.), la zona del alto río Ramos era parte de los territorios que dominaba el gran sitio de Hervideros, a $3 \mathrm{~km}$ de distancia. Este lugar se había creado dentro de la gran empresa colonizadora, por medio probablemente de una alianza entre varios grupos, que formaron un sitio con abundante población de más de 30 hectáreas construidas. Como se trataba de una comunidad recién asentada en un nuevo territorio, esta sociedad tenía una gran preocupación por su defensa. Debido a ello, los habitantes de Hervideros crearon un sistema estratégico defensivo para controlar el territorio circundante y poder prevenir ataques de las zonas vecinas.

Para comprender la importancia estratégica de la ubicación del sitio de Hervideros y del valle del alto río Ramos, hay que tener en cuenta que se encuentran al final de un gran corredor norte-sur, el valle del río Santiago, que se inicia al sur, próximo al valle de Guadiana, junto al nacimiento del río Mezquital-San Pedro, importante eje de comunicación este-oeste (fig. I). La sierra de la Candela, al pie de la cual está la confluencia de los ríos Santiago y Tepehuanes para formar el río Ramos, es el límite norte de este gran corredor del río Santiago. El lugar donde se encuentra Hervideros, a $3 \mathrm{~km}$ de la confluencia, es donde el camino al norte se bifurca en dos para rodear la sierra de la Candela. El camino hacia el este es el camino del alto río Ramos.

En ese sistema estratégico que construyeron los hervidereños, el alto río Ramos tenía un papel importante, ya que era una zona que no se podía ver desde Hervideros, y además desde ahí partían dos caminos importantes de entrada y salida al alto río Ramos y, al norte del valle de Santiago, al territorio de Hervideros. Por estas razones se armó un sistema de defensa y control del área. Con tal fin, se ocuparon dos cerros prominentes en el alto río Ramos. Esos cerros eran La Tutuveida, al inicio del valle, al sur, y El Olote, al norte (fig. 2).

La parte septentrional del alto río Ramos era como una frontera hacia el norte y una puerta de entrada hacia el sur. Hacia el norte se abría una zona más árida, accidentada, sin corrientes de agua permanentes en un gran territorio. Sólo siguiendo el cañón de Pichagua se llegaba hasta el valle bajo del río Ramos, con asentamientos chalchihuiteños. Hacia el sur se abría un gran territorio chalchihuiteño, primero del alto río Ramos y, más allá, el gran valle de Santiago.

El abandono del asentamiento de Hervideros a finales de la fase anterior hace probable que, al menos, parte de los habitantes se trasladaran al alto río 


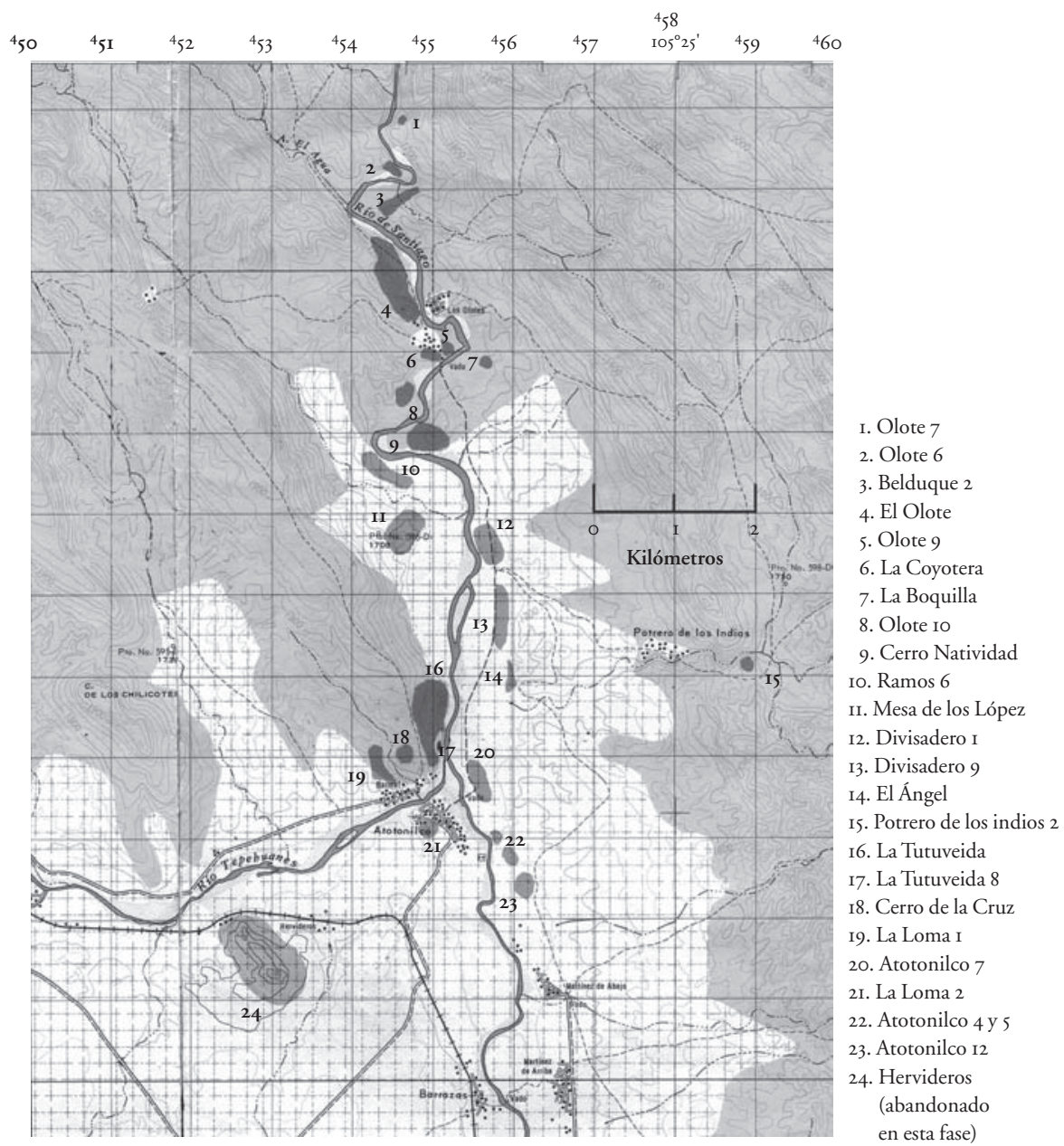

2. Paisaje chalchihuiteño del río Ramos en la fase Tunal-Calera, con los dos cerros: El Olote y La Tutuveida. Realización del autor.

Ramos, en donde la ocupación se intensifica, y este territorio se organiza de manera autónoma al no depender de ningún centro rector afuera del valle.

La distribución del asentamiento obedece ahora a tres criterios principales: la cercanía al río de curso permanente, la cercanía a tierras de cultivo de la primera terraza y la consolidación de un sistema estratégico defensivo. 
En esta nueva organización se observa poca diferenciación social entre los miembros de la comunidad. Los ajuares pobres de los entierros y la escasez de piezas suntuarias indican que no había un sistema de prestigio social muy desarrollado. Analizando la arquitectura se infiere que en ninguno de los sitios del valle se localizó un área de residencia de un grupo de elite. El patrón de asentamiento del valle refleja una jerarquía poco desarrollada y poco compleja. Se va confirmando la idea de una sociedad formada por personas que a la vez son agricultores y guerreros, en la que no caben grandes diferencias. ${ }^{6}$

\section{Sitios de arte rupestre}

En el espacio objeto de estudio se han descubierto dos conjuntos de arte rupestre, localizados en los sitios La Tutuveida, al sur, y El Olote, al norte. ${ }^{7}$

\section{El Olote}

El sitio El Olote se halla al norte del valle, donde éste empieza a estrecharse hasta culminar en la boca del cañón de Pichagua, que representa el límite norte (fig. 2). Se sitúa sobre un cerro que está al borde del río Ramos, cerro que tiene una posición estratégica, ya que domina visualmente esta zona norte con la entrada al cañón, y hacia el sur tiene una buena vista de este valle y del final de la cuenca de Santiago, además de contacto visual con La Tutuveida, aunque no se divisa el sitio Hervideros. El cerro en sí mismo tiene buenas características para un asentamiento defensivo, ya que sus laderas son bastante empinadas, especialmente las de las vertientes norte, este y sur. En la vertiente oeste, con una pendiente menos pronunciada, las culturas que ocuparon el lugar construyeron terrazas y muros defensivos.

6. Hers, "Zacatecas y Durango...", op. cit.

7. El análisis del conjunto de arte rupestre de La Tutuveida tiene como base el registro realizado por Marta Forcano (El arte rupestre..., op. cit.). Sin embargo, en este análisis complemento las ausencias y señalo las diferencias que he advertido en este registro. De las expresiones de arte rupestre del sitio El Olote yo mismo realicé el registro con la colaboración de Marie-Areti Hers, Félix Hernández, Luis Miguel Quintero y varios alumnos de la Escuela Nacional de Antropología e Historia: Martha Guadalupe Mendoza Camacho, Margarita Álvarez González, Bárbara Glendi García Alquicira, Nadia Castillo Mares y Daniel Herrera Maldonado. 


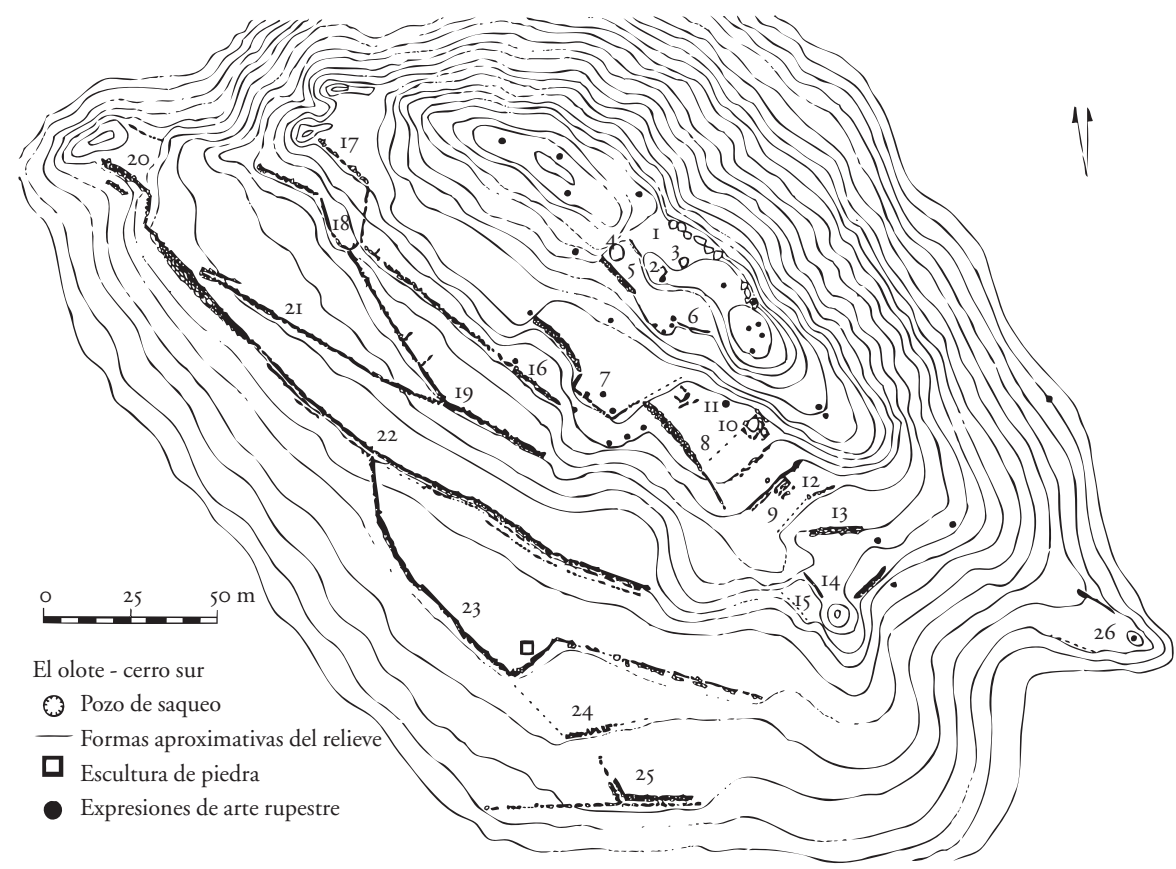

3. Plano del sitio El Olote: cerro sur. Levantamiento topográfico: Fernando Berrojalbiz y Marie-Areti Hers. Dibujo del autor.

Las expresiones de arte rupestre en este sitio se encuentran mayoritariamente en la parte superior. La cima de este cerro está constituida por una crestería rocosa muy accidentada, en dirección sureste-noroeste. Esta crestería desciende en forma de escalones hacia el sureste, mientras que por el norte la caída es abrupta.

La crestería está interrumpida en la mitad de su extensión por un espacio menos accidentado, que ha sido aprovechado por el hombre para modificarlo y crear un espacio humanizado. Se construyeron pequeñas terrazas con sus muros para nivelar espacios a distintas alturas y se dispusieron algunas estructuras de pequeño tamaño. A lo largo de toda la crestería, incluido el espacio humanizado, se han encontrado la mayor parte de las expresiones rupestres.

Además de lo observado en la crestería, se hallan manifestaciones rupestres en terrazas situadas inmediatamente bajo el espacio humanizado, al oeste, y en las terrazas que descienden hacia el sureste: 7, 8, I2 y I3 (fig. 3). 
Todas las expresiones encontradas en El Olote se realizaron mediante la técnica del grabado. Siguiendo las ideas de Marta Forcano ${ }^{8}$ y Marie-Areti Hers? sobre el arte rupestre chalchihuiteño, las imágenes que se han encontrado en El Olote corresponden a dos de los tres temas que se han reconocido dentro de dicho arte: uno se ha denominado vulvas, canales y piletas, y el otro narraciones míticas. El tercer tema, denominado los cuadriláteros, no se ha descubierto en El Olote.

A continuación voy a realizar una descripción general de las expresiones que se encuentran en este sitio. No pretendo hacer una investigación exhaustiva del arte rupestre del asentamiento porque sobrepasa los alcances de este trabajo y sólo me detendré en los motivos importantes para sustentar las ideas aquí expuestas.

El tema de vulvas, canales y piletas está constituido por la asociación de varios motivos, aunque éstos aparecen también aislados. Existen piletas o pocitos excavados en la roca, de varios tamaños. Se pueden dividir en dos tipos por el tamaño: a) las que oscilan alrededor de los $5 \mathrm{~cm}$ de diámetro y las que tienen más de $15 \mathrm{~cm}$ de diámetro, que presentan una profundidad mayor a Io $\mathrm{cm}$ y alcanzan los $30 \mathrm{~cm}$ en ocasiones. La mayoría pertenece al primer tipo, con menos de $5 \mathrm{~cm}$ de profundidad. En algunas rocas aparecen conjuntos de pequeñas piletas, a veces alineadas, o la asociación de una pileta grande con una pequeña; en otras rocas existe una pileta grande aislada; pero en los demás casos se asocian con canales.

De gran parte de estas piletas, sobre todo de las más pequeñas, salen unos pequeños canales excavados en la roca, estrechos y poco profundos, de I a $3 \mathrm{~cm}$ de ancho y I $\mathrm{cm}$ de profundidad, que descienden hasta la base de la roca, hasta la tierra (fig. 4). Estas expresiones aprovechan el relieve de la roca para transmitir mejor sus significados, para hacerlos más realistas (fig. 5). Estos canales tienen una forma ondulante, sinuosa, que recuerda el movimiento de los arroyuelos formados por el agua de las lluvias torrenciales, aunque también la forma de una serpiente.

Aislados o entre estas piletas y canales se encuentran unos motivos formados por círculos grabados, con una línea vertical que los atraviesa en su interior, o como una especie de herradura ancha grabada que deja un espacio interior estrecho resaltado semejante a una línea interior vertical, como el caso anterior (fig. 6). Estos motivos representan vulvas, órganos sexuales femeninos, ya que son similares a como están representados estos órganos en las figurillas

\footnotetext{
8. Forcano, El arte rupestre..., op. cit.

9. Hers, "La música amorosa...", op. cit.
} 
4. Roca con canal grabado que sale de un pocito en la parte superior y desciende hasta

la tierra. El Olote. Fotografía del autor.

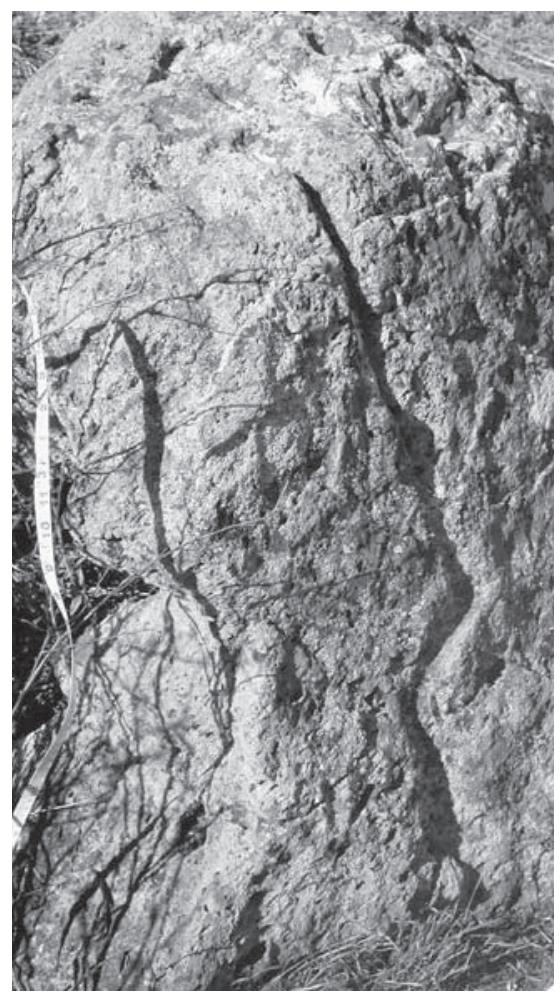

cerámicas o en las representaciones antropomorfas femeninas en otros conjuntos de arte rupestre chalchihuiteño, como veremos más adelante en La Tutuveida o en el sitio Salto del Perro, también en Durango. ${ }^{\text {Io }}$

La denudación de la roca en este cerro adopta formas como círculos u óvalos en relieve con el centro hueco y el exterior del círculo aplanado (como la forma de los panes dulces llamados donas). Debido a esto en muchas ocasiones no se distingue bien si son expresiones realizadas intencionalmente por la mano del hombre o si son formas naturales. Sin embargo, es posible que para los chalchihuiteños esto no tuviera mucha importancia. Probablemente, en un proceso de retroalimentación, la realización de las vulvas en la roca de ese cerro y el simbolismo que le estaban atribuyendo se desplazaba a las formas naturales similares y, de manera paralela, la presencia que estas formas naturales sugiere, 


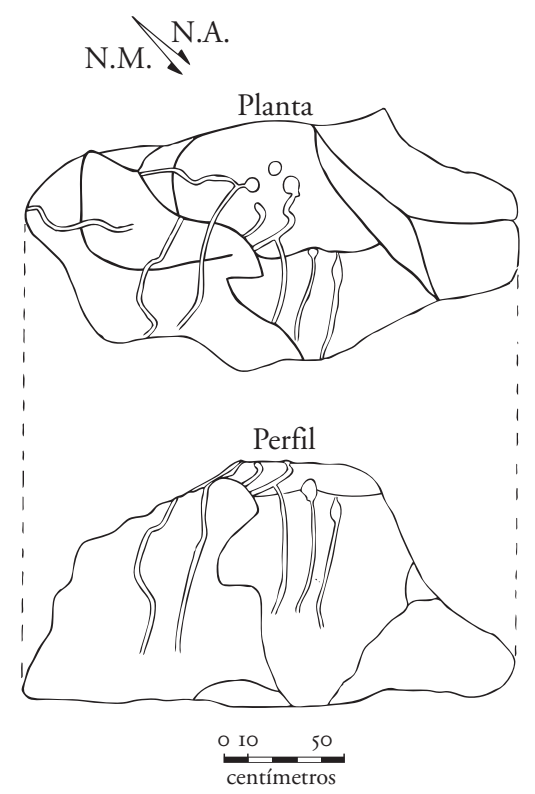

5. Dibujo de roca con grabados. En la parte superior hay unos pocitos de los que salen canales que descienden por la roca. El Olote. Dibujo del autor.

inspiraba a los chalchihuiteños los mensajes que emanaban de este cerro, y la manufactura de las vulvas.

El segundo tema, el de las narraciones mitológicas, tal como ha sido definido por Hers, lo constituyen los motivos figurativos: representaciones de seres humanos, animales cuadrúpedos, serpientes, aves y astros. ${ }^{\text {II }}$ Este segundo tema ha sido llamado "narraciones mitológicas" por la relación que parecen tener estos motivos con la cosmovisión y la mitología de los pueblos de la Sierra Madre Occidental y del suroeste de Estados Unidos. En El Olote se encuentran representaciones de venados y serpientes (figs. 7 y 8), dos motivos antropomorfos, uno de ellos dudoso, y lo que podría ser un motivo astral.

La imagen de la serpiente es similar a muchos de los canales ondulantes que salen de las piletas y caen por la piedra hasta el suelo, pero en los dos casos en que aparece esta imagen tiene representada la cabeza de una serpiente en el extremo. Estas imágenes se encuentran en un afloramiento rocoso que marca el límite noreste del espacio modificado de la cumbre, y en otro afloramiento al pie de este espacio, hacia el oeste.

II. Hers, "La música amorosa...”, op. cit., p. 315. 


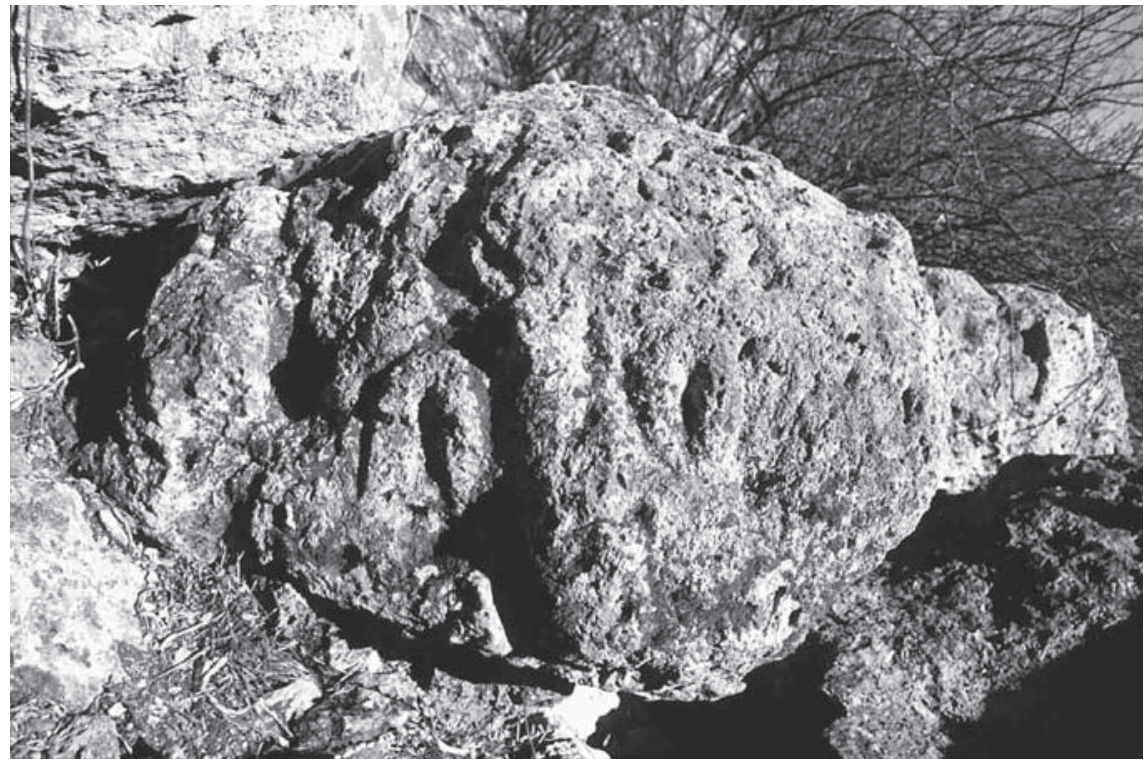

6. Roca con dos vulvas grabadas. El Olote. Foto: Marie-Areti Hers.

Los dos venados grabados en El Olote están representados de perfil, mediante unas líneas que dibujan el contorno del animal de una manera esquemática, con un estilo muy parecido. Uno de ellos tiene un tamaño mayor que el otro: $40 \mathrm{~cm}$ de longitud por 30 de alto, mientras que el otro tiene $10 \mathrm{~cm}$ de longitud por Io de alto (fig. 7 ). El venado mayor se encuentra en la parte sureste de la crestería, junto a una piedra que tiene un grabado que puede ser un antropomorfo. En cambio, el venado más pequeño se encuentra en una roca grande en la parte alta de la terraza 8 , en la que también se observan pequeños pocitos, de dos de los cuales salen canales. Esta roca se halla pegada al afloramiento rocoso del este de la terraza, junto a una roca con vulvas (fig. 6). Estos venados son muy similares en su estilo a los encontrados en el sitio chalchihuiteño de La Mesa de la Cruz, Coscomate, valle del río Zape, y en general a los que se encuentran en los sitios chalchihuiteños del noroeste de Durango. ${ }^{\text {I2 }}$

Los dos motivos antropomorfos son muy diferentes, aunque en ambos casos son bastante esquemáticos. El motivo que se encuentra en el extremo sur de la crestería, junto al venado grande, está representado con una circunferencia 

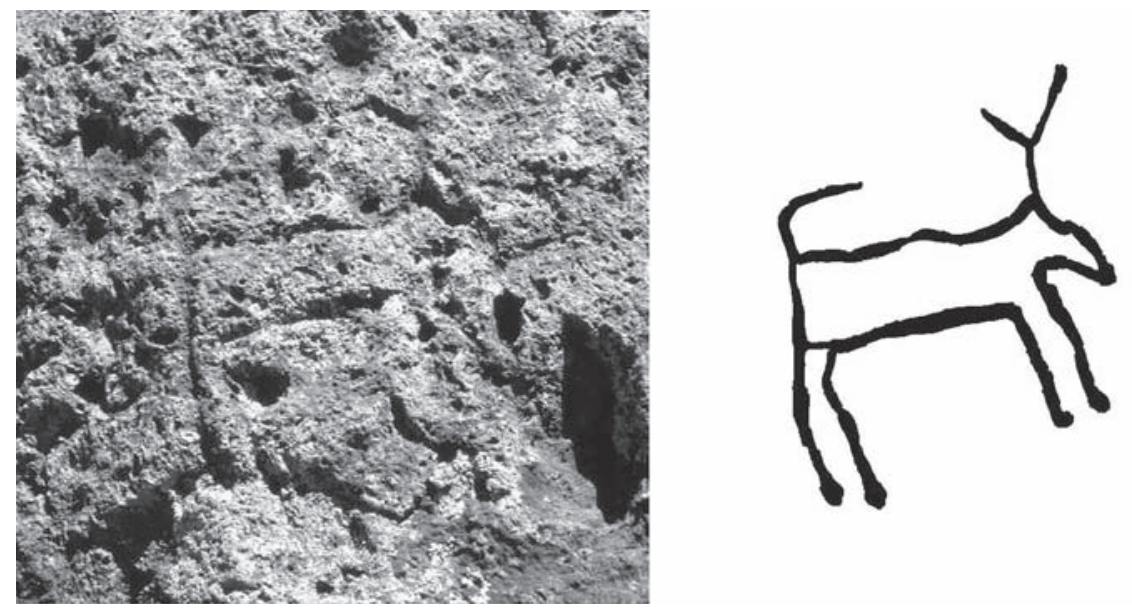

7. Venado grabado en la roca y su dibujo al lado. El Olote. Foto: Marie-Areti Hers. Dibujo del autor.

grande como cuerpo del que salen la cabeza y los brazos, extendidos hacia arriba, y las piernas en forma de líneas hacia abajo. El brazo izquierdo está conectado con un elemento vertical que puede tratarse de algún tipo de estandarte.

El otro motivo antropomorfo es de más dudosa identificación. Se halla en la parte norte de la crestería, en una roca un poco aislada del resto de las expresiones. Una de las interpretaciones de este motivo es que representa a un flautista.

La técnica utilizada para realizar los grabados parece ser el picoteado de la roca o la percusión directa con instrumentos de otras rocas más duras, seguidas en algunos casos de una abrasión ligera, y en el caso de las piletas grandes de una abrasión o pulido más intenso, aunque las paredes regulares y pulidas que presentan las piletas de gran tamaño pueden ser el resultado de la combinación de estas técnicas con la acción del agua.

Aunque las diferencias no son muy notables, los motivos realizados con más regularidad, los más definidos y los más elaborados parece que se hallan en la parte sur de la crestería.

\section{Atribución de las expresiones a la cultura chalchihuiteña}

Creo que las expresiones de arte rupestre encontradas en El Olote corresponden a la cultura chalchihuiteña, por las razones siguientes: 

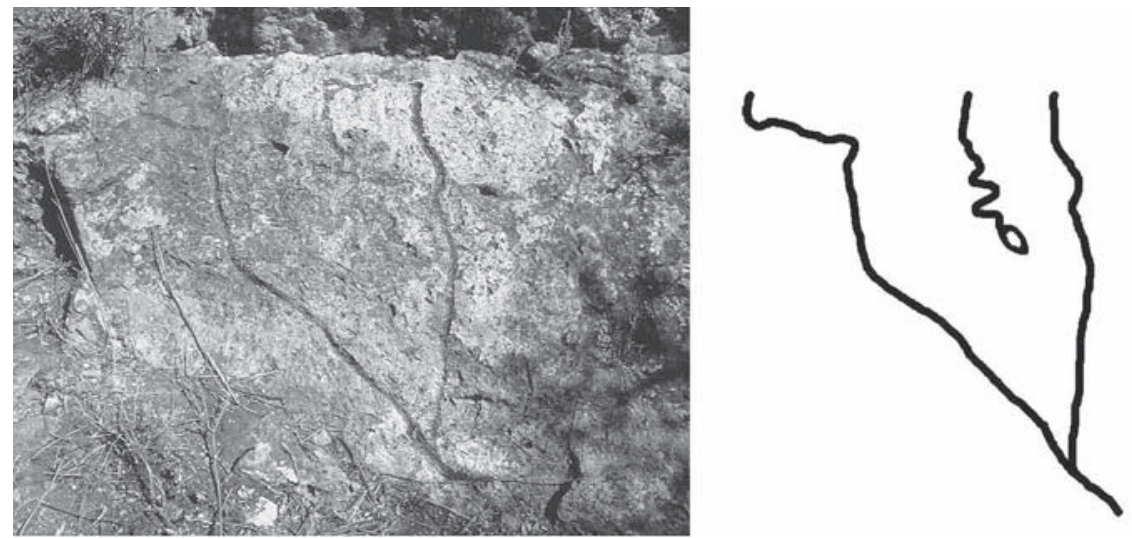

8. Serpiente grabada junto con dos canales y su dibujo al lado. El Olote. Foto: Marie-Areti Hers. Dibujo del autor.

I) Son similares a otras de diversos sitios chalchihuiteños, en cuanto a los temas principales de esta cultura, la iconografía, el estilo y la técnica. Además de estas semejanzas, que se han ido comentando al describir los motivos, se ha observado que algunos grabados forman parte de muros de terrazas y edificios chalchihuiteños: G22, en el muro noreste del espacio modificado de la cumbre, y, G42, en mitad del muro de la terraza I2. La roca Gi8 forma parte del edificio 2 en la cumbre. Esto también ocurre en otros sitios chalchihuiteños de Durango, como en Mesa de la Cruz, en el valle del río Zape, donde ciertos grabados están en las piedras que forman los cimientos de las casas chalchihuiteñas; también en el sitio de Gomelia, en un paso estrecho que da acceso al sitio, hay unas rocas en las que se encuentra este tipo de motivos; ${ }^{13}$ otro sitio que tiene muchas semejanzas con El Olote es El Capulín, en el alto Tepehuanes, en donde grandes rocas, que son parte de los muros de edificios, tienen grabados similares. ${ }^{\text {I4 }}$

2) La mayoría de los materiales encontrados en el sitio corresponden a la cultura chalchihuiteña; entre ellos destacan la cerámica, figurillas cerámicas, esculturas de piedra, la lítica y gran parte de la arquitectura.

13. Ibidem, p. 295.

I4. Christophe Barbot, "Habitat et populations agricoles préhispaniques dans le bassin du río Tepehuanes, Durango, Mexique”, tesis doctoral en Arqueología, París, Université de Paris I (en preparación). 
3) En las excavaciones de la escalera que limita la terraza 8 por el sur, terraza en la que hay algunas expresiones rupestres junto al edificio Io, se obtuvieron unas fechas que corresponden a la ocupación chalchihuiteña de esta zona: una fecha de Ci4 calibrada en 984 de la era y otra fecha de termoluminiscencia de $889 \pm 77$ de la era. ${ }^{15}$

Merece la pena comentar brevemente las semejanzas que tiene el arte rupestre de este sitio con otros asentamientos del norte de Durango, ya que nos habla de ciertos simbolismos, de ciertos mensajes que se repiten y que, por tanto, eran importantes para los chalchihuiteños. De estos sitios, en la mayoría de los casos no se cuenta con la suficiente información para conocer el paisaje simbólico en que estaban inscritos. El primer lugar lo constituye el cerro Hervideros, de cuyo territorio formó parte El Olote. En este sitio se halló una roca con innumerables vulvas y se tienen noticias de que en el área donde se ubica se han encontrado esculturas tanto zoomorfas como antropomorfas y fálicas. Además, en otras partes del sitio se han hallado pocitos de los que salen canales. Sin embargo, hay una ausencia total de cuadriláteros.

Los otros dos sitios son Coscomate, en el valle de Zape, y El Capulín, en la cuenca alta del Tepehuanes, ambos sobre cerros. Estos dos lugares presentan expresiones que tienen muchas similitudes con El Olote, así como también su distribución en el sitio. Pero las semejanzas se notan desde la ubicación y la arquitectura de los mismos. Se localizan sobre cerros estratégicos, lo mismo que el sitio Hervideros. Sobre la cima de ellos se encuentran construcciones relacionadas con las manifestaciones rupestres, que a veces forman parte de las construcciones. En general, se puede advertir que el tema de los pocitos, canales y vulvas se halla en la parte superior, cerca del centro del sitio, mientras que motivos que han sido englobados en el tema de las narraciones míticas, como antropomorfos, motivos astrales y venados, se ubican en partes más bajas: en mitad de la ladera y hacia el exterior del sitio. En Coscomate, en partes bajas se han observado unos cuadriláteros, pero son pocos y parecen oponerse a las vulvas que aparecen en la parte alta. Las similitudes son más evidentes entre El Olote y El Capulín.

I5. Las características de las dos fechas son las siguientes: CI4 = Lab. y núm. de muestra: Instituto Nacional de Antropología e Historia, I880; fecha convencional antes del presente: ${ }_{1063}$ \pm 29; fecha calibrada de la era: 984; fecha con I sigma: 966-Io05; fecha con 2 sigmas: 896-Ior8. Termoluminiscencia = Lab. y núm. de muestra: I. Geofísica-Universidad Nacional Autónoma de México. 


\section{La Tutuveida}

El sitio La Tutuveida se ubica sobre un cerro, al inicio del valle del alto río Ramos, sobre la ribera izquierda del río Ramos (fig. 2). Las construcciones se hallan en diferentes partes del sitio: en la zona norte del cerro, en la cumbre, al sur de ésta y en el puerto situado al oeste, que separa este cerro de una mesa grande y alargada. Aunque no se conserven construcciones, los materiales continúan en la parte sur del cerro, con menor densidad, hasta casi llegar, aguas arriba, al pueblo de Barreal. Al sureste existe una zona de derrumbamientos de grandes rocas de las paredes del cerro y se levanta una peña que separa el cerro del río. En las paredes de la peña que dan al río están los paneles donde se ha grabado el conjunto de imágenes más importante (fig. 9). A unos Ioo m hacia el norte de los grabados, también al pie del cerro y en la orilla del lecho del río se encuentran unos manantiales de agua caliente.

Aparte de este conjunto principal, existen unas pocas rocas con piletas y canales en la parte alta del sitio, más cerca de las construcciones, pero no se han encontrado vulvas.

\section{Conjunto principal}

Al contrario que en el sitio El Olote, el conjunto más importante de arte rupestre no se halla en la parte superior, rodeado por la zona habitacional, sino en un extremo del cerro, al pie de él, en una peña frente a la confluencia de ríos, y junto a manantiales de agua caliente.

Para describir las expresiones del conjunto principal, se seguirá y se resumirá el registro hecho por Forcano, ${ }^{16}$ aunque se completarán algunos datos suyos y se comentarán ciertos desacuerdos con su análisis.

Este conjunto principal se ha dividido en varios conjuntos, del I al VI. Como ya se comentó, en cuanto al sitio El Olote, se realizará una descripción general del arte rupestre de La Tutuveida, para luego enfocarse en los paneles que sirven mejor para los propósitos de este trabajo.

En las paredes de un frente rocoso de $25 \mathrm{~m}$ de altura se distribuye un total de 6 conjuntos en paneles de pequeñas dimensiones y poco accesibles (fig. Io). Se disponen de manera vertical, a distintas alturas, concentrándose la mayoría en 


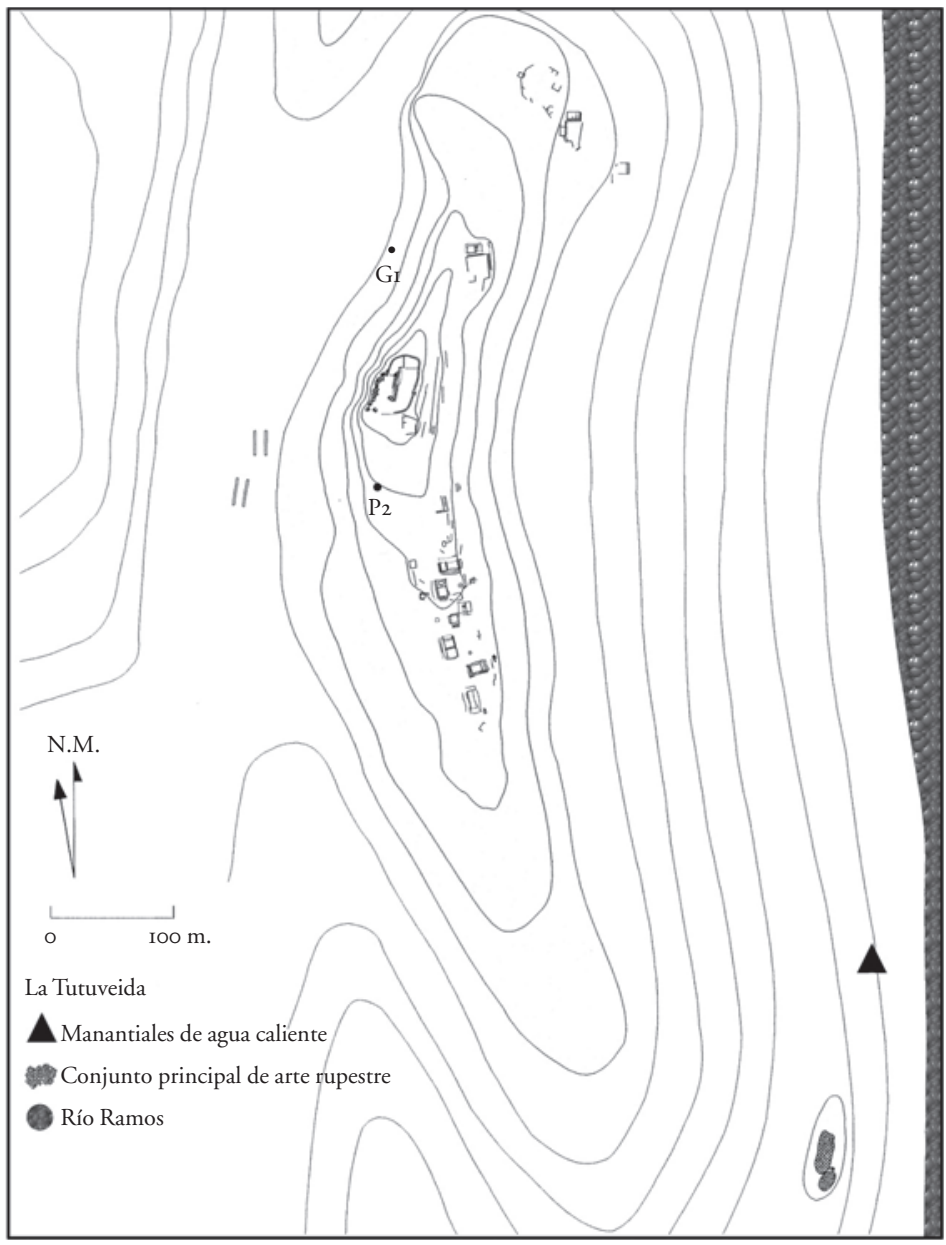

9. Plano del sitio La Tutuveida. Levantamiento topográfico: Fernando Berrojalbiz, Anne Leyniers y Angélica Medrano. Dibujo del autor.

un pequeño espacio situado a Io $\mathrm{m}$ del suelo. Todas las expresiones están hechas mediante la técnica de grabado. Las superficies rocosas en las que aparecen estos grabados son paneles de pequeñas dimensiones, la mayoría de ellos ubicados en lugares de difícil acceso y con muy poco espacio disponible al pie de ellos. En los conjuntos III, IV y V, situados a más de Io $\mathrm{m}$ del nivel del suelo, es necesario 


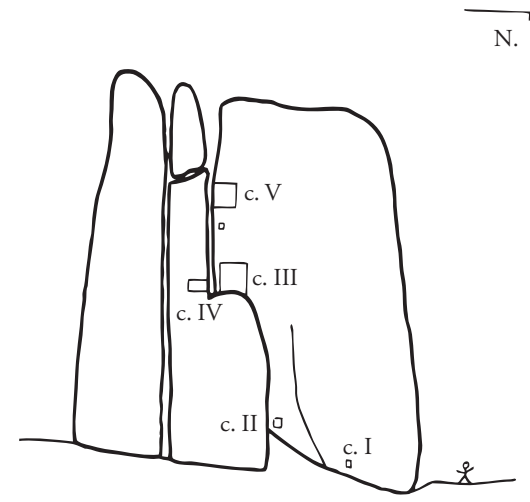

Io. Croquis de vista frontal del conjunto principal de arte rupestre de La Tutuveida.

Dibujo de Marta Forcano.

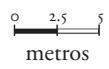

ascender por las rocas para llegar a un reducido espacio donde difícilmente caben más de dos personas. No se pudo llegar al conjunto $\mathrm{V}$, situado en la parte más alta, para poder estudiar de cerca todos los detalles. Aun así, se pudo tener un registro del conjunto. También hay que señalar que algunos paneles, como el conjunto III, fueron recubiertos con una pintura de aceite de color azul.

El conjunto VI, por sus motivos (aparece un jinete sobre un caballo), por el tamaño de las imágenes y por el estilo parece corresponder a una época más reciente, por lo que no me voy a ocupar de él.

En la parte superior del frente en el que se encuentran los grabados, sobre las rocas, parece haber existido una plataforma realizada artificialmente, aunque no se puede establecer esto con seguridad.

Los motivos de estos paneles consisten en su mayoría en cuadriláteros, aunque también hay otros como círculos, óvalos, líneas rectas combinadas en diversos ángulos, antropomorfos, motivos astrales, una posible serpiente y una estructura reticular. Los conjuntos I, II y IV tienen pocos motivos; los más complejos son los de los conjuntos III y V. A continuación voy a describir de manera más amplia estos dos conjuntos, los más importantes para este trabajo. 


\section{Conjunto III}

A media altura del frente rocoso, a unos io m del suelo, se ubica esta agrupación formada por varios motivos entre los que predomina el cuadrilátero (fig. II). Los motivos que se encuentran al este del panel están parcialmente fragmentados debido al desconchado de la pared. Bajo los cuadros inferiores (motivos 8 y 9) se observan rastros y partes aisladas (motivos io y II) de unos motivos muy erosionados, de tal manera que hoy en día no se puede reconocer cabalmente cuáles eran, aunque sospecho que uno de ellos podría ser un cuadrilátero con entramado de líneas en su interior.

En la parte superior izquierda del panel principal se distingue un grupo de líneas rectas (motivo 5) que se combinan en diferentes ángulos y, junto a ellas, un cuadrilátero (motivo 6) que tiene la base más ancha que su parte superior, y en cuyo interior se observan varias líneas entrecruzadas. Es posible que el motivo 5 consista también en un cuadrilátero irregular con líneas que se cruzan en su interior, pero parece que el borde izquierdo de la imagen ha sufrido procesos de erosión, por lo que esta parte se encuentra incompleta.

A la derecha existe un antropomorfo (motivo 7) de reducidas dimensiones, constituido por un trazo longitudinal que se prolonga entre las piernas y señala el órgano sexual masculino, y que en su parte superior se redondea para formar la cabeza. Dos trazos horizontales que se doblan en ángulo hacia abajo constituyen las extremidades. Este antropomorfo está unido mediante una línea que sale de su rodilla al cuadrilátero (motivo 6).

En la parte inferior derecha se observan dos cuadriláteros fragmentados (motivos 8 y 9) que presentan una decoración interna similar compuesta por líneas rectas que se entrecruzan formando un complejo entramado; en el interior de ambos existe un elemento circular con líneas delgadas que irradian de su centro, las cuales podrían ser esteliformes o soliformes. Estas líneas delgadas o rayos parecen haberse hecho con alguna herramienta filosa. En el interior del motivo 9 se observa también un punto entre las líneas interiores inferiores.

Un único motivo se encuentra aislado del resto de imágenes y situado en un plano diferente, en la parte inferior izquierda del conjunto. Se trata de un pequeño cuadrilátero (motivo 4 ) de grabado delgado y muy superficial, apenas visible. Posee en su interior varias líneas rectas que parten del centro de la figura hacia lados opuestos, además de una línea curva en forma de $U$ invertida en su parte inferior. En el cuadrante superior izquierdo formado por las líneas internas existe un punto. 
II. Dibujo del conjunto III del sitio La Tutuveida. Dibujo de Marta Forcano, corregido por el autor.

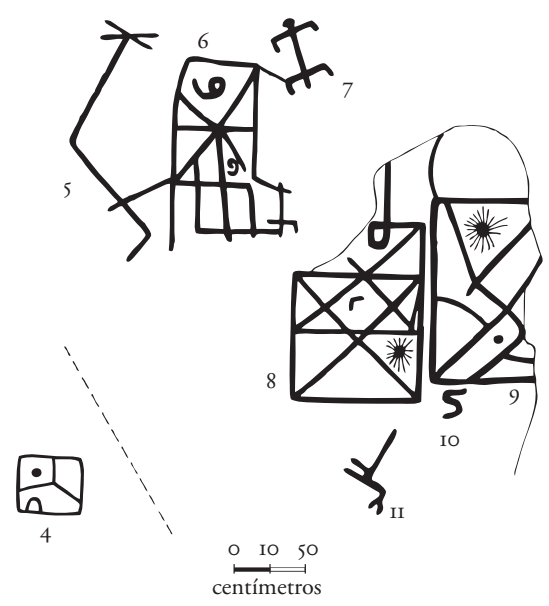

\section{Conjunto $V$}

Está formado por un grupo de motivos que se encuentra en la parte alta del frente rocoso, a 5 metros arriba del conjunto anterior, en un área de muy difícil acceso; $2 \mathrm{~m}$ debajo de este panel se localiza un grupo de motivos que no es fácil identificar. Se trata de una serie de cuadriláteros de diferentes tamaños y formas, dos triángulos unidos por su vértice y un motivo de forma dudosa, en apariencia un antropomorfo con rasgos de ave, todos ellos realizados con variadas técnicas de grabado. Tal grupo de motivos no va a tratarse en este estudio, ya que, debido a su ubicación en un lugar bastante inaccesible y a causa de la acción de la erosión, no se tiene un registro adecuado de él.

El panel principal de este conjunto $V$, situado en la parte superior, está compuesto por varios motivos diferentes (fig. I2). El motivo I7 es un cuadrilátero que posee en su interior varias líneas que se originan en el centro y parten hacia los extremos del cuadro formando un motivo astral, estelar o solar. El cuadrado tiene en su parte inferior tres pequeños trazos verticales que cuelgan hacia el exterior a modo de flecos (fig. I3).

El siguiente cuadrilátero (motivo I8), de mayores dimensiones, presenta como decoración interna varias líneas onduladas que forman una combinación compleja, y de su lado inferior cuelgan una serie de io líneas a modo de flecos. De éstas, la línea del extremo derecho termina en curva hacia arriba, y en otros dos casos son líneas rectas que se juntan con los dedos de la mano de un persona- 
I56 FERNANDO BERROJALBIZ

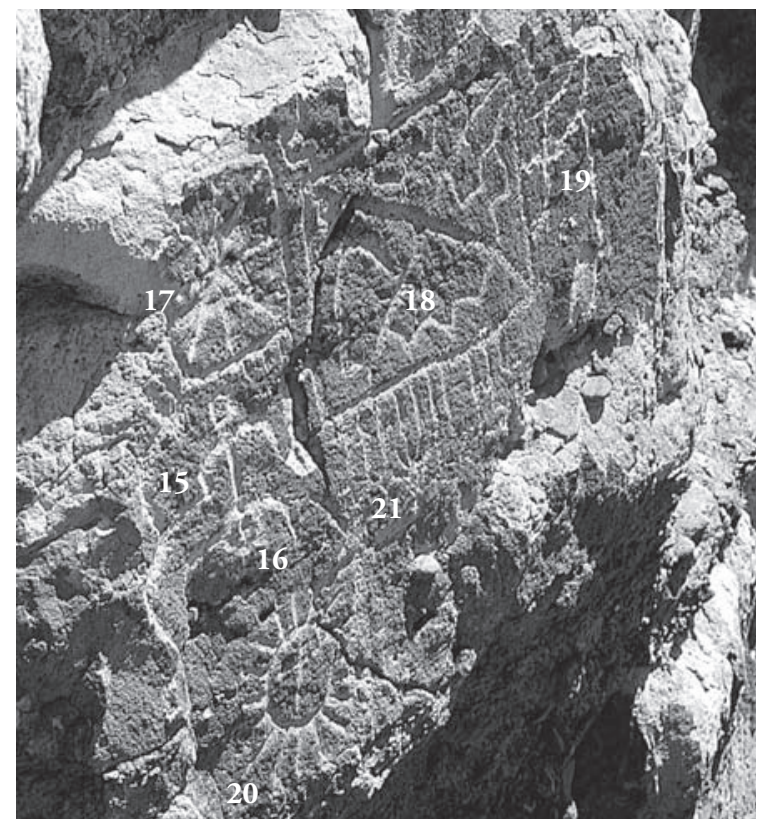

I2. Conjunto V del sitio La Tutuveida. Foto: Marta Forcano.

je (motivo 2I). En las demás, la línea inicia vertical y cambia de dirección en un ángulo pronunciado; incluso algunas se convierten en zig-zag, a modo de rayos.

El motivo I9 se halla asociado al cuadrilátero I8 (fig. I4). Creo que se puede identificar algo más que un grupo de líneas curvas, como dice Forcano en su registro. Si se compara con otros conjuntos de arte rupestre chalchihuiteños, como el de Las Adjuntas, cerca del Cerro del Huistle, en la frontera entre Zacatecas y Jalisco, ${ }^{17}$ creo que se trata de un antropomorfo. Tiene un brazo que toca o toma el cuadrilátero, mientras que del otro, extendido hacia arriba, pende un objeto que consiste en una línea vertical acabada en un círculo. El tronco se dobla para tocar el cuadrilátero, o bien se trata de una pierna. En la parte superior la cabeza está representada por una forma ovalada, y de la parte superior de ella sale una línea hacia arriba, que podría representar una pluma o un tocado.

La relevancia de esta asociación de antropomorfo con cuadrilátero ha sido ya comentada dentro del arte rupestre chalchihuiteño: podría tratarse de personajes que portan escudos. ${ }^{18}$ Además, Forcano, en su análisis, resalta la

17. Fauconnier y Faba, op. cit.

I8. Forcano, El arte rupestre..., op. cit.; Hers, "La música amorosa...", op. cit., p. 313. 
I3. Conjunto V del sitio La Tutuveida, detalle de los motivos I5, I6, I7, 20 y 21.

Foto: Marta Forcano.

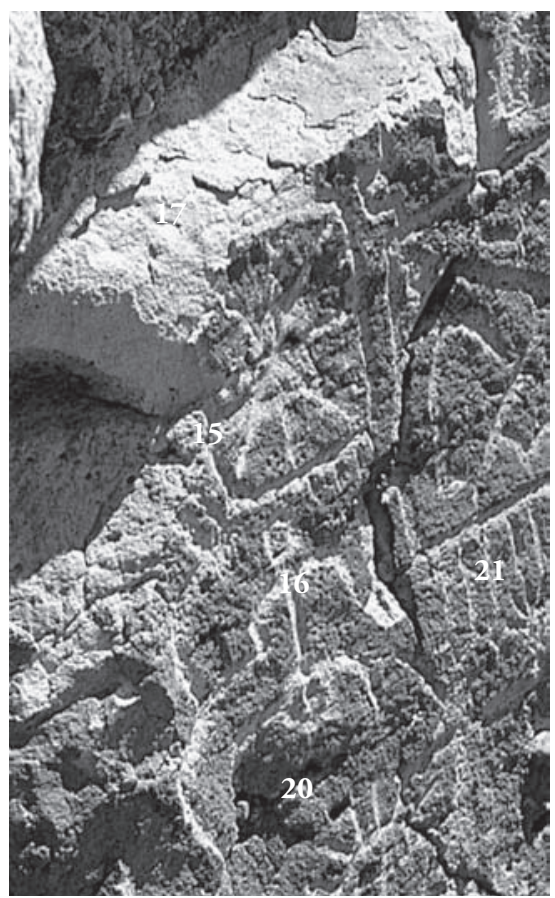

importancia de la asociación de cuadrilátero y antropomorfo en este sitio de arte rupestre. ${ }^{19}$

A la izquierda del panel el motivo is se halla asociado al motivo i6, una representación antropomorfa femenina (fig. I3). Este último motivo está constituido por un círculo que forma la cabeza, un trazo longitudinal para el tronco, y trazos transversales arqueados hacia abajo para las extremidades. En el extremo del tronco, de donde parten las piernas, se observa un pequeño círculo con un punto en el interior, representación que podría corresponder al órgano sexual femenino, similar a la figurilla de barro hallada en El Olote. Este personaje femenino toma o sostiene con la mano el motivo I5. Según Forcano, este último motivo es un utensilio o arma sin identificar. En mi opinión, podría tratarse de una serpiente. La forma ondulada se asemeja al cuerpo de la serpiente y el semicírculo en su parte superior, más bien de forma ovalada, sería la cabeza. En la cosmovisión mesoamericana, la mujer y la serpiente tienen una estrecha relación.

19. Forcano, idem. 
158

Debajo de ese grupo existe un motivo astral o irradiante (motivo 20) con trazos externos que irradian a la manera de rayos; en su interior hay un cruciforme de grabado más delgado (fig. I3). A su lado aparece un antropomorfo con tocado en forma de una especie de pluma y con una gran mano circular y dedos detallados (motivo 2I) que tocan dos de los flecos del cuadrilátero superior (motivo I8). El antropomorfo presenta incompleta su parte inferior, cuyo grabado es más superficial y de rasgos más imprecisos que el resto del motivo. Está conectado con el motivo soliforme por varios rayos.

En el arte rupestre chalchichuiteño también aparece en bastantes ocasiones un antropomorfo asociado a un círculo. En el sitio de Las Adjuntas, entre Zacatecas y Jalisco, varios antropomorfos se asocian tanto a escudos cuadrangulares como a circulares. En este sitio, por el momento, se ha observado que sólo los antropomorfos asociados a escudos cuadrangulares tienen la misma posición que el motivo 2I del panel de La Tutuveida, sobre todo una mano abierta con los dedos extendidos hacia arriba, de frente al espectador. ${ }^{20}$

En cuanto a la técnica, todos los motivos han sido realizados mediante el grabado por percusión y únicamente en algunos trazos se observa la incisión. En unos pocos motivos el grabado no es profundo, sino superficial, y parece así, más que percusión, un raspado, como en el motivo $2 \mathrm{I}$.

Las diversas expresiones de arte rupestre de La Tutuveida corresponden a la cultura chalchihuiteña. Las razones de esta atribución son dos: I) las expresiones son similares a muchos otros conjuntos rupestres chalchihuiteños, por los temas, por los motivos, por el estilo y por la técnica. Hay que recordar que los cuadriláteros son uno de los motivos más frecuentes del arte chalchihuiteño en el norte de Durango. La ubicación del grupo principal y de las demás expresiones de arte rupestre también son similares a otros conjuntos chalchihuiteños. ${ }^{2 \mathrm{I}} \mathrm{La}$ gran mayoría de los materiales, la arquitectura y la organización del sitio corresponden a la cultura chalchihuiteña, por lo que una de las ocupaciones del lugar, tal vez la más importante, fue de esta cultura; se obtuvo una fecha de Ci4 en un buen contexto, II6I d.C. (calibrada), ${ }^{22}$ según la cual hubo una ocupación del sitio en el periodo en que los chalchihuiteños se asentaron en la zona.

20. Fauconnier y Faba, op. cit.

2I. Forcano (en preparación), op. cit., Hers, "La música amorosa...”, op. cit.

22. Las características de esta fecha son: Lab. y núm. de muestra: Beta II2590; fecha convencional antes del presente: $890 \pm 60$; fecha calibrada de la era: II6I; fecha con I sigma: IO37-I2I9; fecha con dos sigmas: IOI9-I279. 
I4. Conjunto V del sitio La Tutuveida, detalle de los motivos I8 y 19 . Foto: Marta Forcano.

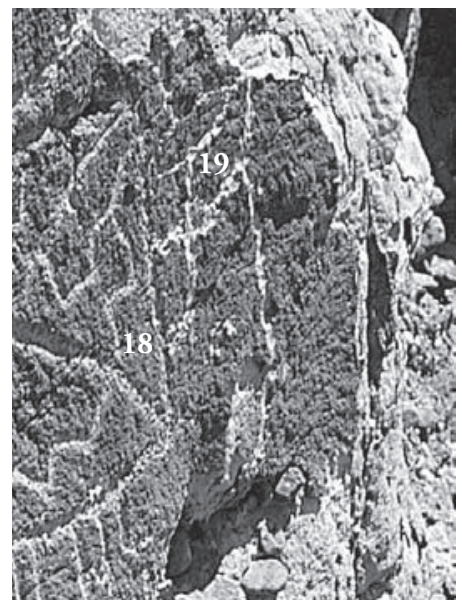

\section{Esculturas en los cerros}

Las esculturas de piedra son abundantes en la cultura chalchihuiteña y se han encontrado en la mayoría de las ocasiones en cerros con evidencias de ocupación de esta cultura, y en estrecha relación con expresiones rupestres. En el alto río Ramos se descubrieron cuatro esculturas, tres de las cuales se hallaron en los dos cerros: La Tutuveida y El Olote.

En el sitio La Tutuveida se encontró una escultura antropomorfa y fálica (fig. I5) en la excavación de un edificio de dos cuartos levantado sobre una plataforma que forma parte del patio I. La escultura se encontraba sobre un piso del cuarto norte cerca del muro oeste de dicho cuarto. Quizá podría corresponder a un culto doméstico.

En esta escultura la cabeza es desproporcionada, pues representa la mitad de la pieza, lo que muestra la importancia de esta parte en el conjunto de la obra. Las dimensiones de esta escultura son $15 \mathrm{~cm}$ de alto, $13 \mathrm{~cm}$ de ancho y II $\mathrm{cm}$ de espesor. Dicha cabeza tiene forma pentagonal y el extremo apuntado en la zona de la barbilla. La cara es la parte más trabajada. La zona de los ojos y de las mejillas se realizó mediante un hundimiento del plano de la cara, mientras que la frente y la nariz se dejaron salientes, presentándose la nariz como una protuberancia. Los ojos y la boca se señalaron mediante un grabado poco acentuado y de forma alargada. En el ojo derecho hay un círculo pequeño y 


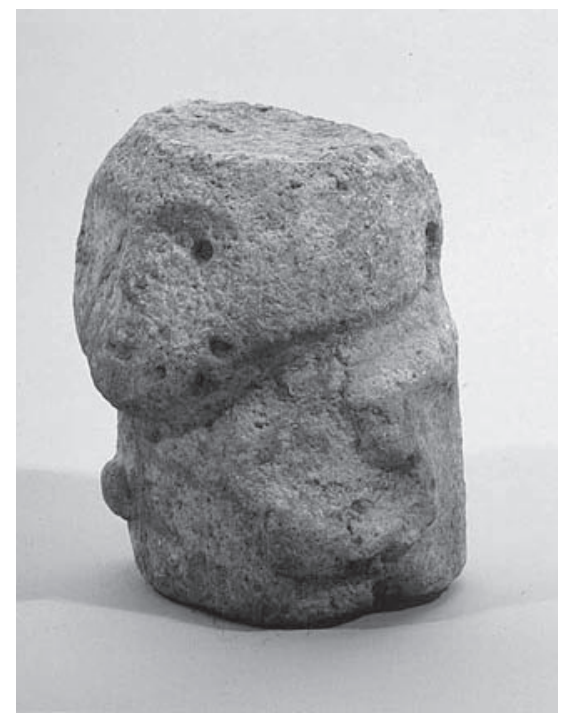

I5. Escultura de piedra

de La Tutuveida.

Foto: Pedro Ángeles.

Archivo del Proyecto Hervideros del

Instituto de Investigaciones Estéticas de la

Universidad Nacional Autónoma de México.

profundo, y no queda claro si es una irregularidad de la piedra o si se hizo intencionalmente para marcar ese ojo. Uno de los rasgos más sobresalientes de la escultura es que en la parte superior de la cabeza se excavó una pileta no muy profunda, que cubre toda esta parte superior. En la pileta se observan restos de sustancias quemadas.

La cabeza de la escultura está separada del cuerpo por una especie de acanaladura en toda su extensión, menos en un pequeño tramo de la parte trasera. Esto refuerza el parecido de la escultura con un órgano sexual masculino, la cabeza sería la parte del glande.

El cuerpo, que representa la mitad de la escultura, tiene forma de columna maciza, con los hombros y los brazos marcados en un ligero relieve. Los brazos están flexionados, aunque pegados al cuerpo, y las manos se apoyan en el torso. Los dedos de las manos están marcados mediante finas incisiones.

La piedra es toba riolítica, porosa, con la superficie irregular. Algunas de las irregularidades, como agujeros naturales, han sido aprovechadas para crear la imagen.

El recipiente excavado en la cabeza contiene restos de sustancias quemadas, lo cual parece relacionarlo con el fuego. Al respecto quisiera realizar una comparación con uno de los pueblos que vive en la actualidad en la Sierra Madre Occidental, el huichol, que podría haber heredado rasgos culturales de los 
I6. Escultura fálica hallada en El Olote. Vista de perfil. Foto: Pedro Ángeles. Archivo del Proyecto Hervideros del Instituto de Investigaciones Estéticas de la Universidad Nacional Autónoma de México.

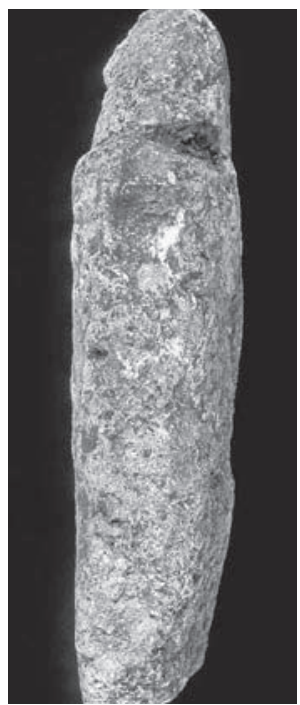

chalchihuiteños. ${ }^{23}$ En el templo principal de sus centros ceremoniales, colocan una escultura de piedra que representa al dios del fuego, Tatewari, enterrada en el suelo del templo, justo debajo del fuego central; es decir, que la lumbre queda sobre su cabeza. ${ }^{24}$

En un extremo del mismo patio I, en la superficie, se encontró una cabeza de piedra, antropomorfa, de pequeño tamaño. Sus dimensiones son $8 \mathrm{~cm}$ de alto, $4.5 \mathrm{~cm}$ de ancho y $7 \mathrm{~cm}$ de espesor. Se observa que está fragmentada en la parte del cuello, por lo que se deduce que formaba parte de una escultura más grande. En la parte superior de la cabeza no hay una pileta excavada. En general, da la impresión de tener una especie de casco o yelmo puesto. La roca parece ser del mismo tipo que la anterior: toba riolítica porosa, con irregularidades.

En el sitio El Olote, en la superficie de una de las terrazas más largas y amplias de las construidas en el flanco occidental del cerro (terraza 23), se encontró una escultura de gran tamaño (fig. I6). Sus dimensiones son $5 \mathrm{I} \mathrm{cm} \mathrm{de} \mathrm{alto,} 20 \mathrm{~cm}$

23. Ángel Aedo, "Imágenes de la sexualidad y potencias de la naturaleza. El caso de las esculturas fálicas chalchihuiteñas de Molino, Durango", Anales del Instituto de Investigaciones Estéticas, México, Universidad Nacional Autónoma de México-Instituto de Investigaciones Estéticas, vol. XXV, núm. 82, 2003, pp. 57-68; Fauconnier y Faba, op. cit.

24. Arturo Gutiérrez, La peregrinación a Wirikuta, México, Instituto Nacional de Antropología e Historia/Universidad de Guadalajara, 2002, p. 64. 
de ancho y $10.5 \mathrm{~cm}$ de espesor. Su cabeza es antropomorfa, aunque se encuentra estilizada, con los rasgos marcados esquemáticamente. De hecho, tiene forma triangular, con el vértice hacia la parte superior, y acaba de forma redondeada en la cima. No tiene excavada una pileta en la parte superior. De la cara sólo tiene marcado el toro supraorbital, que continúa hacia el centro para crear la nariz, en una forma triangular también esquemática.

La separación entre la cabeza y el cuerpo es bastante marcada. Una acanaladura ancha, irregular, separa ambas partes. El cuerpo es macizo, de forma tabular y bastante alargado. El frente y el lado izquierdo están bastante bien regularizados y forman un ángulo recto. En cambio, el lado derecho y la parte trasera no están bien regularizados. No se hallan marcadas las extremidades superiores ni las inferiores. La base es recta y está trabajada, aunque falta un poco de regularización.

La escultura en general ofrece un aspecto macizo y la forma de la pieza en conjunto se asemeja al órgano sexual masculino. La cabeza antropomorfa sería el glande.

Como Hers afirma, en otros sitios chalchihuiteños estas esculturas se encuentran relacionadas con conjuntos de arte rupestre donde se representan los motivos que aparecen en El Olote: vulvas, canales y pocitos. Incluso en el sitio Coscomate, en el valle de Zape, una de estas esculturas apareció en el interior de una pileta. ${ }^{25}$

\section{Elementos para la aproximación al paisaje simbólico}

Para adentrarnos en los mensajes de estas expresiones es necesario considerar que formaban parte esencial del paisaje simbólico construido por los chalchihuiteños en el alto río Ramos, y que tal paisaje se constituyó con diversos elementos y superponiendo varias perspectivas y concepciones. A continuación voy a comentar varios de esos elementos y perspectivas.

\section{Aspectos estratégicos y territoriales}

Este pequeño valle escondido del alto río Ramos era un espacio de gran importancia estratégica, como ya se ha explicado más arriba, tanto en la primera época 
de la ocupación chalchihuiteña, dependiente del cercano sitio Hervideros, como en la segunda, en la que se organizó de manera autónoma.

Por su carácter de puerta de entrada y salida, este territorio tenía una consideración especial, tanto en su relación con otras comunidades de su cultura, como dentro de las creencias de sus habitantes, relacionadas con el orden del universo y sus dioses. En ese pequeño valle se habían grabado en la roca expresiones de su pensamiento político y simbólico en relación con su territorio. Dispusieron que los especialistas grabaran esos signos en la roca en dos sitios, La Tutuveida y El Olote, uno en cada extremo de ese espacio, al norte y al sur. Ese pequeño valle del alto río Ramos conforma un territorio cotidiano para sus habitantes, que se recorre a pie en dos horas, disponiendo cada uno de estos cerros de una buena visión del otro.

Estas expresiones se pudieron empezar a grabar en la primera etapa del desarrollo chalchihuiteño, pero quizá se fueron completando, y se añadieron motivos y significados en la segunda.

Uno de los temas más representados en el arte rupestre de Durango es el de los cuadriláteros. Éstos, en muchas ocasiones, se hallan asociados a antropomorfos, a un personaje que carga el cuadrilátero, como ocurre en el conjunto de La Tutuveida (fig. I4). Una de las interpretaciones de estas figuras es que son escudos cargados por personajes, como ya se ha mencionado. De acuerdo con esta interpretación, cada escudo representa un grupo social. Los escudos podrían representar dos mensajes: ${ }^{26}$ uno de diferenciación de grupos sociales, pues todos los escudos tienen motivos distintos asociados y no hay dos iguales; pero también un mensaje de alianzas entre grupos al haber muchos escudos diferentes reunidos, que están superpuestos, ensamblados o unidos por una línea. En estos mensajes se advertiría en principio que no hay grupos superiores a otros, ya que todos tienen un valor parecido. Sin embargo, también hay que señalar que puede haber cierta jerarquía entre estos cuadriláteros por su ubicación en el panel, su tamaño y por su entrelazamiento con otros, por lo que es posible que hubiera ciertas diferencias entre los grupos de la comunidad. Pero parece que no se trata de grandes diferencias sociales y que el desarrollo de la jerarquía social es mínimo. ${ }^{27}$

\section{Idem.}

27. Fernando Berrojalbiz, "Los paisajes prehispánicos del alto río Ramos, Durango, México", tesis de doctorado en Antropología, México, Universidad Nacional Autónoma de México-Facultad de Filosofía y Letras, 2005. 
I64

FERNANDO BERROJALBIZ

Otra de las explicaciones de los cuadriláteros es la de que simbolizan las rutas de las migraciones que realizaron los pueblos chalchihuiteños, en comparación con la forma que tienen los hopis de Arizona de señalar y relatar sus migraciones históricas y míticas. ${ }^{28}$ Recordemos que los chalchihuiteños colonizaron estos parajes a raíz de una emigración emprendida desde el sur, desde Zacatecas, y que inicialmente, al principio de la era, habían partido desde el centro de México. Estos mensajes se entienden en el contexto de un asentamiento creado después de una gran migración, asentándose en una tierra nueva, y los consiguientes afanes por estabilizar esa ocupación, por lo que es bastante probable que se grabaran durante la primera etapa colonizadora. También están en consonancia con una sociedad donde la guerra estaba entretejida con los demás aspectos de su cultura.

Los grabados en el cerro del norte, El Olote, tienen otro tipo de mensajes, los cuales ponen en comunicación los niveles celestes con los de la Tierra y los del inframundo, como se verá más adelante. Sin embargo, la presencia de estos conjuntos de arte rupestre en los dos cerros que dominan la entrada y salida del valle muestra que uno de sus mensajes y una de sus dimensiones simbólicas corresponden a los de marcadores territoriales. Estas expresiones las dispusieron a la vista de los dioses y de todos los pobladores y todos los extranjeros que llegaran, para que supieran de quién era el territorio. Las de La Tutuveida transmitían mensajes más cargados de asuntos del orden político y social, de cómo los dioses les habían guiado en sus migraciones hasta ahí, y de sus alianzas, que cimentaban la organización sociopolítica de su comunidad; además, las colocaron junto a los manantiales de agua caliente.

\section{Espacios simbólicos}

En el sitio El Olote, la parte superior del cerro se compone de una crestería rocosa interrumpida en la mitad por un espacio modificado por los chalchihuiteños.

Se trata, como ya se ha comentado, de un espacio nivelado por varias terrazas pequeñas de distintas alturas, que muestra un elaborado trabajo de construcción. Se conserva un pequeño edificio en el centro pegado a una roca con grabados. Pudo haber más edificios de esa época que ahora no se conservan 
por las remodelaciones posteriores y la destrucción del tiempo. El espacio está rodeado por varias rocas con grabados rupestres. Sin duda, era un espacio con una significación muy especial, en la cima, rodeado por expresiones rupestres y con una de ellas en el centro (fig. 3).

La Tutuveida es el sitio que se encuentra al sur del territorio. A lo largo de este sitio hay tres espacios simbólicos diferentes que conforman el significado de este lugar. El primero de ellos se encuentra en la cumbre. En ella se realizó una gran modificación y nivelación del terreno para crear una explanada amplia y asentar sobre ella, al poniente, una gran plataforma, sobre la cual creo que se encontraba un templo, y en su extremo norte se construyó un edificio pequeño, que podría ser un adoratorio (es posible que en el extremo sur hubiera otro pequeño edificio, otro adoratorio, pero las evidencias son dudosas; fig. 17). Si se observa que La Tutuveida está sobre un cerro cuya parte superior es bastante escarpada y apuntada a la manera de una pirámide, se puede considerar que el cerro podía simbolizar una pirámide mesoamericana.

En la parte superior del cerro se encuentra la plataforma más grande del sitio, seguramente el templo, el cual representa los niveles celestes del universo, de la misma manera que ocurría en la parte superior de las pirámides mesoamericanas. Las ceremonias, rituales que se celebraban en este lugar, eran seguidas por toda la comunidad y afectaban a todos.

Otro espacio sagrado muy importante de este sitio es donde se ubican los dos juegos de pelota, en un puerto o "cajón” al oeste del cerro donde se asienta el sitio (fig. 9). En este lugar no hay más construcciones que los dos juegos de pelota, ubicados no en el centro del puerto, sino un poco más pegados al cerro La Tutuveida, uno al noroeste del otro y con orientaciones distintas. Este espacio no contaba con otras construcciones porque estaba dedicado únicamente a la ceremonia del juego de pelota, juego al cual asistía toda la comunidad. Incluso la ladera oeste del cerro La Tutuveida, que se encuentra muy próxima a los juegos, podía servir de gradería para observarlos. Además, desde el espacio en la cumbre hay una buena visión de los juegos.

Esos juegos, amén del carácter lúdico, tenían una gran trascendencia para toda la comunidad. En algunos casos, según Hers, ${ }^{29}$ había una estrecha relación entre el juego de pelota y la guerra en la cultura chalchihuiteña. La misma autora refiere el caso de dos sitios fortificados donde el juego de pelota se encuentra en la parte más protegida y señala que "quizás en ciertas circunstancias el azar

29. Hers, “Zacatecas y Durango...", op. cit., p. I47. 


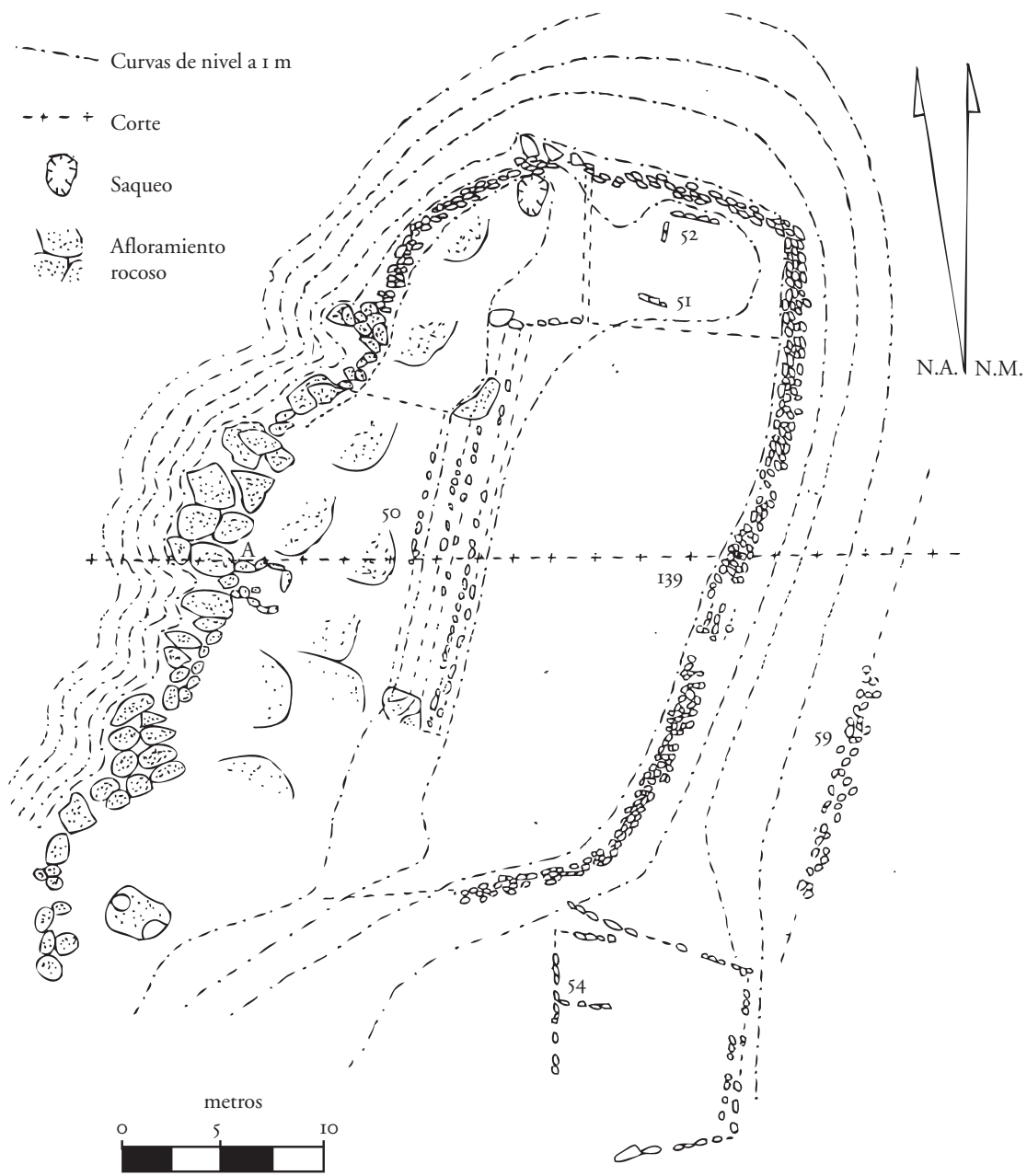

17. Plano de la cumbre modificada de La Tutuveida. La estructura 50 es la plataforma mayor del sitio, sobre la que probablemente habría un templo. Dibujo del autor.

del juego sustituía el incierto desenlace bélico". ${ }^{30}$ También comenta que entre los acaxee, herederos de la cultura chalchihuiteña en la parte alta de la Sierra Madre Occidental de Durango, las apuestas y desafíos que se cruzaban entre dos pueblos, consignadas en las fuentes del siglo XviI, se parecían a un encuentro

3o. Idem. 
guerrero ritualizado. En otras partes de Mesoamérica, para el Clásico final y el Posclásico, como en uno de los juegos de pelota de Chichén Itzá, los relieves esculpidos representan jugadores de pelota con atuendos de guerreros, y el juego de pelota "se convirtió en un principal culto de Estado en Chichén Itzá, fundiéndose y complementándose con el inveterado simbolismo cosmológico y marcial del deporte con el de los cultos de guerreros que iban en ascenso" ${ }^{3 \mathrm{I}}$ En la zona maya se relaciona al juego de pelota con la simbolización de la guerra. ${ }^{32}$

Además, el juego de pelota en Mesoamérica tiene una simbología relacionada con la continuidad de los ciclos astrales y la fertilidad. La confrontación de los jugadores en el juego representaba la lucha cósmica entre las fuerzas terrenales y el inframundo, y las fuerzas celestes, así como también las confrontaciones entre grupos humanos. ${ }^{33}$

El lugar donde se encuentra el conjunto mayor de las expresiones rupestres es indudablemente uno de los espacios simbólicos más importantes de La Tutuveida. Parte esencial de él la constituyen los manantiales de agua caliente, que se hallan a una distancia no mayor de $100 \mathrm{~m}$ (fig. 9). En la cultura chalchihuiteña muchos sitios de diferentes características, como los habitacionales, sagrados o defensivos, se asocian a fuentes de agua caliente, pero todavía no ha sido explorado con profundidad el significado de este nexo bastante recurrente.

Tampoco es un tema tratado con detalle en los estudios mesoamericanistas. Las culturas del centro de México en la época cercana a la conquista son las más estudiadas al respecto. La distancia cronológica y cultural entre los chalchihuiteños y pueblos como los mexicas y los purépechas es grande. Voy a señalar algunos aspectos sobre la simbología alrededor del agua en estas últimas culturas en el intento de que sirvan de orientación general para explorar el significado en la cultura chalchihuiteña. Estoy consciente de que no se puede aplicar mecánicamente el pensamiento de estas culturas del Posclásico tardío a la duranguense, algunos

3I. Jeff Karl Kowalski, "Las deidades astrales y la fertilidad agrícola: temas fundamentales en el simbolismo del juego de pelota mesoamericano en Copán, Chichén Itzá y Tenochtitlán”, en María Teresa Uriarte (comp.), El juego de pelota en Mesoamérica. Raíces y supervivencia, México, Siglo XXI (Colección América nuestra, 39), 1992, p. 327.

32. Mercedes de la Garza y Ana Luisa Izquierdo, "El juego de los dioses y el juego de los hombres. Simbolismo y carácter ritual del juego de pelota entre los mayas", en Uriarte (comp.), op. cit., p. 323.

33. Kowalski, op. cit., pp. 325-328; de la Garza e Izquierdo, idem.; Felipe Solís Olguín, "El sagrado juego de pelota en la capital de los mexicas", en Jordi Fernando (coord.), El juego de pelota en el México precolombino y su pervivencia en la actualidad, Barcelona, Fundació Folch/Museu Etnològic/Ayuntament de Barcelona/Consejo Nacional para la Cultura y las Artes/Instituto Nacional de Antropología e Historia-Museo Nacional de Antropología, I992, pp. I45-I46. 
siglos anterior, pero en la oscuridad actual sobre la cuestión pueden aportar bastante luz. No hay que olvidar que la cultura chalchihuiteña se empezó a desarrollar en territorios de Zacatecas y del sur de Durango como resultado de una migración procedente del centro de México, a comienzos de la era, ${ }^{34}$ y que en su aventura norteña tuvieron intenso contacto con grupos purépechas que a su vez habían emigrado hacia el norte. Después ambos grupos retornaron hacia el sur: los chalchihuiteños participaron luego en la formación de Tula y los purépechas retornaron a su lugar de origen para refundar su cultura. ${ }^{35}$

Las historias y mitos acerca de la migración de los mexicas supone uno de los ámbitos de su cultura donde con mayor riqueza se expresa su simbolismo. En uno de los episodios de esta historia se narra la lucha entre Huitzilopochtli y Copil, hijo de la hermana hechicera del primero, y cómo éste mata a su sobrino, cortándole la cabeza y arrancándole el corazón. Según algunas versiones, tal lucha tiene lugar en un pequeño cerro, Tepetzinco (hoy el Peñón de los Baños, cerca del aeropuerto de la ciudad de México), al pie del cual hay manantiales de agua. Al morir Copil, supuestamente junto a dichos veneros, éstos se convierten en agua caliente. ${ }^{36}$ Otras versiones cuentan que Huitzilopochtli ordenó a un guerrero que arrojara aquel corazón en un tunal y carrizal en el lago, y que cayó junto a una cueva en la que brotaba agua caliente ${ }^{37}$ y éste es el lugar en donde va a germinar más tarde el nopal sobre el cual se posaría el águila, señal del sitio donde Huitzilopochtli indicaría que se construyera su gran ciudad.

Muy cerca del cerro Tepetzinco se encontraba el remolino o sumidero del Pantitlán, donde, según cuenta fray Diego Durán, aparte de otras características del lugar, hierve el agua y ésta arroja espuma. En él se echaban ofrendas de los sacrificados. ${ }^{38}$

34. Marie-Areti Hers, Los toltecas en tierras chichimecas, México, Universidad Nacional Autónoma de México-Instituto de Investigaciones Estéticas (Cuadernos de Historia del Arte, 35), 1989.

35. Patricia Carot y Marie-Areti Hers, "La gesta de los tolteca-chichimecas y de los purépechas en las tierras de los pueblos ancestrales”, en Carlo Bonfiglioli, Arturo Gutiérrez y María Eugenia Olavaria (comps.), Las vías del Noroeste, vol. I: Una macrorregión indígena americana, México, Universidad Nacional Autónoma de México-Instituto de Investigaciones Antropológicas (en prensa).

36. Fray Diego Durán, Historia de las Indias de Nueva España e islas de Tierra Firme, México, Consejo Nacional para la Cultura y las Artes (Cien de México), 2002, t. I, pp. 80-82.

37. Fernando Alvarado Tezozómoc, Crónica mexicáyotl, Adrián León (trad. directa del náhuatl), México, Universidad Nacional Autónoma de México-Instituto de Investigaciones Históricas, I992, pp. 43 y 63.

38. Johanna Broda, "Cosmovisión y observación de la naturaleza: el ejemplo del culto de los cerros en Mesoaméria”, en Johanna Broda et al. (comps.), Arqueoastronomía y etnoastronomía en 
De este episodio de la emigración se puede ver que el agua caliente y el lugar donde se encuentra están relacionados con una lucha. Esta lucha se da entre Huitzilopochtli, que representa el dominio de lo solar, y Copil, hijo de una hechicera, con poder sobre animales "ponzoñosos", la cual había entrado en conflicto con el primero y había sido abandonada por mandato de aquél. Se puede decir, por tanto, que representa la oposición entre lo solar y el dominio de lo oscuro, del inframundo. Como resultado de la lucha, Huitzilopochtli corta la cabeza y le arranca el corazón a Copil. Se trata, pues, de una muerte ritualizada, de un sacrificio. Esta lucha es una metáfora de la concepción dual del universo de la tradición mesoamericana, y del eterno conflicto e interacción entre los dos ámbitos. En esta ocasión, y en relación con el agua caliente, se narra la victoria del dominio solar. Del culto al Pantitlán se observa que había agua caliente en este lugar y que estaba muy relacionado con el sacrificio, ya que se echaban importantes ofrendas de los sacrificados.

La Relación de Michoacán es una de las fuentes más importantes para conocer la cultura de los purépechas en vísperas de la conquista. En el fragmento que se conserva de la primera parte se explica la celebración de una fiesta: Sicuindiro. ${ }^{39}$ La diosa preponderante en esta celebración es Cuerauáperi. En esta fiesta, en la que participan varios sacerdotes y se hacen bailes con personajes que representan nubes, se realiza el sacrificio de dos personas. Se arrancan los corazones a los sacrificados y son llevados a un poblado cercano para arrojarlos a una fuente de agua caliente, supuestamente dedicada a esta diosa. En las demás fuentes de agua caliente, dedicadas a otros dioses, se echa la sangre de los sacrificados. Se decía que de los vapores de los manantiales salían las nubes que producían la lluvia, y que estaban a cargo de la diosa Cuerauáperi, y que por esta razón echaban la sangre en las fuentes. De esta diosa se comenta que es la madre de todos los dioses de la Tierra, y que envió a los hombres a vivir en la Tierra dándoles las semillas para sus cultivos. Esta diosa enviaba, también, las hambrunas.

En este texto se observa que el agua caliente está relacionada con el sacrificio; el corazón y la sangre eran arrojados en dicha agua. Este sacrificio se hacía en honor de la diosa Cuerauáperi, encargada de los vapores del agua caliente

Mesoamérica, México, Universidad Nacional Autónoma de México-Instituto de Investigaciones Históricas, I991, p. 482.

39. Jerónimo de Alcalá, Relación de Michoacán, Madrid, Patrimonio Nacional/Ayuntamiento de Morelia/Testimonio, 200I, pp. 260 y 261. 
que se convierten en nubes generadoras de lluvia. Quizá el arrojar el corazón y la sangre a esta agua de donde salen vapores que suben al cielo era un medio de comunicación directo y efectivo de las ofrendas a la diosa. Pero también es importante señalar la relación de esta diosa con la lluvia, con la tierra y con los mantenimientos y los recursos en la Tierra. Por eso está también relacionada con las hambrunas.

De la simbología de los mexicas para entender la relevancia del agua caliente entre los chalchihuiteños, se puede resaltar la relación con una lucha, un conflicto; quizá también con la lucha cósmica entre los dos ámbitos del universo. Además se desprende la relación con el sacrificio y la renovación, y la asociación con el ámbito de lo solar, con la victoria o predominio de lo solar. Con los aspectos considerados de los purépechas hay una coincidencia en la fuerte relación con el sacrificio. Pero los ámbitos con los que además se asocia son los de la lluvia, los mantenimientos y recursos de la Tierra.

Creo que se puede decir que para los chalchihuiteños esta zona de los manantiales de agua caliente tenía una gran importancia, simbólica y sagrada a la vez, como ahondaremos más adelante, y no es de extrañar que se colocaran los grabados en su proximidad.

\section{Culto a los cerros}

Dos cerros, La Tutuveida y El Olote son los dos polos sobre los que se va a conformar el paisaje simbólico de los chalchihuiteños en el alto río Ramos. Los sitios sobre estos cerros eran los principales dentro de la organización social y política, donde se encuentran los espacios y estructuras comunitarias de significación sagrada más importante. Estos significados se sumaban para que dichos espacios se conformaran como los dos polos de referencia del paisaje de sus creencias y su cosmovisión.

Para acercarse a la importancia de estos lugares en la cosmovisión de los habitantes del alto río Ramos hay que considerar la concepción de los cerros en la tradición mesoamericana. Para adentrarme en las ideas de esta tradición voy a reflexionar sobre las culturas del centro de México en el Posclásico final, respecto a las cuales se cuenta con abundantes conocimientos. Pero también porque, como señala Johanna Broda: "las nociones cosmológicas del culto a la lluvia y los cerros surgieron como una cosmovisión estructurada a fines del Preclásico, correspondientes a las primeras culturas importantes de la cuenca, 
como Cuicuilco, Xico, Tlapacoya y, naturalmente, Chalcatzingo". $4^{\circ}$ Como ya he mencionado, la cultura chalchihuiteña surgió en el Norte como resultado de una migración que partió del centro de México a principios de la era, por lo que tiene sentido realizar este tipo de reflexiones, siempre teniendo en cuenta que nos pueden servir de orientación para aproximarnos a las concepciones duranguenses sin que se haga una asimilación automática. Sin embargo, como se verá a continuación, las similitudes sorprenden.

Para los habitantes del centro de México en el Posclásico final, los cerros eran grandes almacenes de agua que se conectaban con las aguas subterráneas, y de ellas salían las que formaban los ríos, los lagos y el mar. Además, el término náhuatl altépetl, pueblo, significaba también "monte lleno de agua". ${ }^{41}$ La Tutuveida podría representar algo relacionado con estas ideas al ser un gran cerro al pie del cual brota el agua, en este caso caliente, que se derrama en el río Ramos.

Por otra parte, se decía que la lluvia procedía de los cerros en cuyas cumbres se engendraban las nubes. Así, el dios de la lluvia, Tláloc, era patrón de los cerros. También se les relacionaba con los pequeños seres que producía la tormenta y la lluvia, tlaloque, servidores del dios Tláloc. En los cerros se hacían sacrificios, de niños especialmente, para la petición de lluvias, que eran muy importantes, entre otras cuestiones para el ciclo agrícola..$^{22}$ En la cima de El Olote son innumerables los canales que salen de pocitos y discurren sinuosamente hasta la tierra, en una clara referencia al discurrir del agua de la lluvia, al culto a la lluvia.

En conexión con lo anterior, estaban las creencias de que el maíz, las demás plantas comestibles, los recursos y las riquezas en general eran guardados en el interior de los cerros, por lo que éstos se consideraban fuente de los mantenimientos. ${ }^{43}$ Por tanto, también estaban relacionados con la fertilidad, ya que de su interior salían las "semillas" de todos los recursos y riquezas necesarias para la vida de los hombres y retornaban a su interior una vez que habían cumplido la parte mundana de su ciclo. ${ }^{44}$ Las vulvas grabadas en El Olote y las esculturas

40. Johanna Broda, "El culto mexica de los cerros de la cuenca de México: apuntes para la discusión sobre graniceros", en Johanna Broda y Beatriz Albores (coords.), Graniceros: cosmovisión y meteorología indígenas de Mesoamérica, México, El Colegio Mexiquense/Universidad Nacional Autónoma de México-Instituto de Investigaciones Históricas, 1997, pp. 49-90.

4I. Broda, "Cosmovisión y observación...", op. cit., p. 480; Graniceros: cosmovisión..., op. cit., p. 53.

42. Ibidem, "Cosmovisión y observación...", pp. 466 y 474.

43. Ibidem, p. 47I.

44. Alfredo López Austin, Tamoanchan y Tlalocan, México, Fondo de Cultura Económica, I994, pp. I6I-I62. 
fálicas halladas en los dos cerros se refieren también a la fertilidad y, junto con las relaciones con la lluvia, podrían hacer referencia a estos lugares como el cerro de los mantenimientos.

Los templos, pirámides y cerros tenían una equivalencia especial. Las pirámides eran edificios con el carácter de templos que reproducían la figura de los cerros. De esta manera se ha sugerido que el Templo Mayor abarcaba en su doble pirámide dos cerros y la pirámide de Tláloc era el Tonacatépetl, "el cerro de los mantenimientos". ${ }^{45}$ A su vez, los templos eran réplicas del cosmos y sus pisos representaban los cielos. ${ }^{46}$ En las dos montañas del alto río Ramos hay construcciones en la cima que forman un lugar sagrado y en La Tutuveida parece que hubo un templo.

Además, los cerros eran sagrados y se concebían como deidades de la lluvia a la vez que deidades telúricas que mandaban las tormentas, el granizo y ciertas enfermedades como la gota y el reumatismo. ${ }^{47}$ También los dioses patrones de las comunidades se transformaban en cerros en el territorio de ellas. ${ }^{48}$

Otra vinculación importante que debe señalarse es la de los cerros repletos de riquezas, el ciclo agrícola, los muertos y los ancestros, así como también los cerros con el origen y la legitimación de los grupos étnicos. ${ }^{49}$

Por todo lo anterior, no es de extrañar que los cerros, en la tradición mesoamericana del Posclásico, tuvieran un papel importante en la cosmovisión y el ritual. Los santuarios en los cerros estaban marcados en el paisaje por vestigios como pequeñas plataformas o patios rodeados de muros, toscas construcciones y amontonamientos de piedras naturales. En muchas ocasiones están asociados a afloramientos vistosos de rocas naturales que están tallados con relieves, petroglifos, "maquetas" y "pocitas" — como refiere Broda— "los cuales constituyen misteriosos vestigios arqueológicos que no han sido interpretados hasta ahora en el contexto adecuado". ${ }^{\circ}$ En el caso de estos cerros del alto río Ramos, en ambos hay construcciones especiales en la cima, además de las que se encuentran en sus laderas, y existen pocitas y petroglifos en afloramientos vistosos de rocas naturales. En este trabajo intento formar una interpretación al respecto.

45. Broda, "Cosmovisión y observación...", op. cit., p. 472.

46. López Austin, op. cit., p. I7I.

47. Broda, "El culto mexica de los cerros...", op. cit., pp. 67-68.

48. López Austin, op. cit., p. 217.

49. Broda, "El culto mexica de los cerros...", op. cit., p. 53.

5o. Ibidem, p. 60. 


\section{Esculturas}

Otro aspecto importante del culto a los cerros, también relacionado con el arte rupestre, con los sistemas simbólicos y con la construcción del paisaje, lo constituyen las esculturas de piedra halladas en ellos. Broda ha señalado que en los cerros existía un culto de las piedras sagradas: "tanto de grandes rocas, o peñas, como de pequeñas imágenes monolíticas con rasgos toscos, casi abstractos, incluyendo los mal llamados ídolos estilo Mezcala". ${ }^{\mathrm{I}}$ La autora propone que estas imágenes pertenecían a cultos agrícolas arcaicos. Uno de los cerros donde más evidencias se han encontrado de estas esculturas, tanto arqueológicas como documentales, es el cerro Tláloc, situado en el límite del valle de México. En la época mexica había un santuario en la cumbre donde se encontraba la estatua de Tláloc rodeada por multitud de pequeños ídolos, representaciones de los otros cerros de la cuenca. La estatua de piedra de Tláloc llevaba en su cabeza un recipiente, lleno de hule derretido, "y en él había de todas semillas". Broda menciona también que en este cerro, como en el de La Malinche, se han hallado esculturas de $2 \mathrm{~m}$ de alto, con rasgos antropomorfos o del dios Tláloc, algunas de las cuales tienen un vago aspecto fálico. ${ }^{52}$ Finalmente, la autora comenta que en el Templo Mayor aparecen infinidad de figurillas de piedra tubulares en el contexto del culto a Tláloc, a las que juzga parte del culto de los tlaloques como cerros deificados. De manera más general, considera que pertenecían al culto mexica de los cerros, el agua y la tierra. ${ }^{53}$

Como ya he comentado, en los dos cerros del alto río Ramos han aparecido varias esculturas de piedra. De las tres halladas, una parece incompleta, conservándose únicamente la cabeza. De las otras dos, la de El Olote (fig. I6) es parecida en su forma y aspecto a las de Tláloc halladas en el cerro Tláloc y en La Malinche. Comparten esa forma entre cilíndrica y tabular, que semeja un falo, más pronunciada en El Olote por la acanaladura que separa la cabeza del tronco. También han sido talladas únicamente en la parte superior, con rasgos correspondientes a la cabeza. La escultura hallada en La Tutuveida, aunque también posee rasgos fálicos, se asemeja más a la descrita en las fuentes, que se ubicaba en el santuario del cerro Tláloc. En la descripción se señala que llevaba en su cabeza un recipiente donde se quemaba hule y semillas, muy parecido al

5I. Ibidem, p. 65 .

52. Ibidem, p. 66.

53. Broda, “Cosmovisión y observación...", op. cit., pp. 469, 472 y 475. 
recipiente excavado en la cabeza de la escultura de La Tutuveida. Páginas antes he comentado que esta escultura podría relacionarse con el fuego, y en el cerro Tláloc se vincula con este dios que, según Broda, también es una deidad de la tierra, y por tanto también se relaciona con el fuego.

Es interesante señalar que la escultura de El Olote, el cerro relacionado con la lluvia, la sexualidad, lo femenino, el inframundo y la fertilidad, como veremos a continuación, representa un falo con menos rasgos antropomorfos y no tiene recipiente en la cabeza con evidencias de fuego. A este respecto hay que señalar que El Olote es el único sitio del valle donde se han encontrado figurillas de cerámica femeninas, con el sexo señalado.

En cambio, la escultura de La Tutuveida, cerro relacionado con lo solar, lo diurno, lo masculino, lo cálido y el fuego, tiene esa concavidad excavada en la cabeza con restos de sustancias quemadas.

Por otra parte, quizá la peña de La Tutuveida donde se grabaron los conjuntos de arte rupestre podría ser parte de ese culto a las piedras sagradas en forma de grandes peñas que señala Broda.

\section{La concepción dual del universo}

La visión del universo como una división y un conflicto entre dos ámbitos, reflejados en innumerables pares de oposiciones, es predominante en el pensamiento mesoamericano. Entre estas oposiciones destacan las de los dos tipos de fuerzas opuestas: los seres fríos y húmedos, relacionados con la época de las lluvias, y los seres ígneos y solares, cálidos y secos, vinculados con las secas. En las expresiones rupestres del alto río Ramos se puede observar también esta concepción polarizada.

En el sitio La Tutuveida, la gran mayoría de las imágenes se refieren a asuntos sociopolíticos y territoriales que estarían vinculados con la guerra, en Mesoamérica relacionada con la época de secas. En las expresiones rupestres dominan los mensajes sobre la identidad de los grupos que conforman la comunidad, sus alianzas y las migraciones que les han traído a estos parajes. A la vez, están marcando un territorio que pertenece a una comunidad determinada. En estos mensajes subyace la idea de defensa del territorio, conflicto y lucha, pero también de orden social.

Es decir que los mensajes se asocian con el dominio cálido y seco, masculino, de la dualidad en que se divide el cosmos en la mentalidad mesoamericana. 
Además, el panel donde se encuentran estas expresiones se orienta hacia el sureste, así que recibe el sol del mediodía, por lo que estas imágenes se podrían relacionar con lo diurno, con el sol del día.

No obstante, también aparece el dominio frío, de la sexualidad, húmedo y femenino por el motivo de la mujer serpentiforme, y por las pocas piletas y canales. La dualidad de la concepción del universo mesoamericano está presente, aunque parece que los significados enfatizan la esfera masculina. El motivo predominante de este conjunto es el cuadrilátero y no aparecen dos motivos de singular importancia en el arte rupestre chalchihuiteño: la vulva y el venado.

En El Olote, las expresiones grabadas transmiten mensajes de la lluvia, del discurrir del agua, de la sexualidad, de lo femenino. Las referencias al erotismo humano, las vulvas y la presencia de esculturas fálicas las ha interpretado Hers como imágenes sagradas que señalan el lugar de encuentro entre la vida y la muerte, como metáforas de la armonía de la naturaleza también reflejada en la unión entre el cielo, la tierra y el inframundo, que se produce cuando el agua de lluvia cae en las piletas y discurre por las rocas hasta penetrar la tierra, ${ }^{54}$ también evocan la fertilidad, el renacer de la tierra, del universo y de los hombres, de la sexualidad. Como explica Alfredo López Austin, la sexualidad en general "pertenece al ámbito femenino del cosmos. Por ello los varones son inferiores a las mujeres en potencia sexual. Mientras el hombre sólo participa en el proceso sexual durante la cópula, la mujer lo domina todo, desde el fenómeno de la menstruación hasta el parto, y más allá, hasta la muerte en el parto." 55

Además, el acto sexual en la mentalidad mesoamericana era concebido "como el enorme pecado de unir las fuerzas opuestas en un abrazo creador" 56 que se relacionaba con la fertilidad, la reproducción y el crecimiento del hombre y del universo, todos estos elementos que corresponden al dominio de los seres fríos y húmedos, oscuros, nocturnos y terrestres. ${ }^{57}$ En este sentido, también son ilustrativas las ideas de Ángel Aedo en un trabajo que relaciona las esculturas chalchihuiteñas antropomorfas y fálicas con mitos y ritos huicholes y hopis del siglo xx: "Por partida doble este mito refuerza por medio de sus referencias al 'vino' [bebida alcohólica de agave] la sexualización del inframundo, fuente primordial de las fuerzas fertilizadoras de la naturaleza, pues uno de los nombres

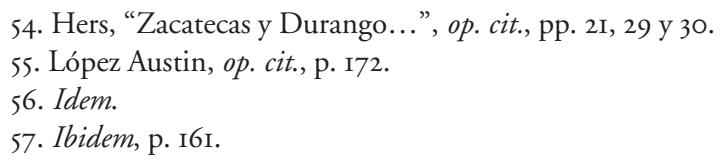


del tallo central de los agaves corresponde al de $h+$ nari, término que entre otras cosas evoca al pene erecto." 58

En la cosmovisión mesoamericana, la morada de los dioses de este dominio de los seres húmedos y fríos es un gran cerro. En el interior del cerro "se atesoran enormes riquezas agrícolas, animales, minerales y las corrientes de agua. Las cuevas son los principales puntos de comunicación con este mundo y los lugares por los que salen vientos y nubes". ${ }^{59} \mathrm{El}$ Olote puede representar, por tanto, la morada de los dioses del dominio húmedo y frío del universo, y el "corazón" de la tierra donde está la fuente de toda la vida en el mundo.

En este conjunto rupestre los motivos dominantes son los canales que salen de pocitas y las vulvas. La ausencia de cuadriláteros es total. En esta diferencia tan marcada entre las expresiones de los dos cerros se descubre una oposición excluyente entre cuadriláteros y vulvas que reafirma la creación de un paisaje donde se plasma una concepción dual, y en cada uno de los cerros se explica un ámbito de esa dualidad. En este sentido, no creo que sea una casualidad que los juegos de pelota estén en el cerro del sur y no en El Olote, como tampoco creo que sea fortuita la presencia de la escultura antropomorfa con el hoyo en la cabeza, asociado al fuego, en La Tutuveida y no en El Olote, así como la presencia de figurillas cerámicas femeninas únicamente en El Olote.

Aedo establece puentes entre el pensamiento de los huicholes actuales y la cultura chalchihuiteña, que ahora conviene tomar en cuenta: en la dualidad mesoamericana, el ámbito de la fertilidad, de la sexualidad, tiene que ver con la muerte, la noche, la locura, la fiesta desmedida, el desorden. ${ }^{60}$ Las vulvas, representaciones de la vagina dentada, de una fuerza inusitada, podrían evocar, entre otras cosas, tal desorden. En cambio, los cuadriláteros, relacionados con los asuntos políticos de las alianzas, la organización social, las migraciones y la delimitación de territorios, remitirían al orden, el ámbito opuesto.

En otros territorios duranguenses hemos observado esta oposición excluyente entre cuadrilátero y vulva. Uno de los paisajes en donde el arte rupestre formula un discurso semejante al del alto río Ramos es el que se localiza en el pueblo de San Nicolás de Presidios, en el valle del río Tepehuanes, $20 \mathrm{~km}$ al noroeste de la región objeto de este trabajo. En ese paraje de Presidios existe un cerro de especial importancia, pues en su cumbre y sus faldas se hallan sitios

58. Aedo, op. cit.

59. López Austin, op. cit., p. I6I.

6o. Aedo, op. cit., pp. 55 y 59. 
con estructuras, rodeados por cinco conjuntos de arte rupestre. Uno de ellos, el más grande, es el conjunto La Candela. En este sitio hay una gran cantidad de expresiones rupestres, dominadas notoriamente por el motivo del cuadrilátero, además de otros relativos al tema de las narraciones míticas: antropomorfos y una variedad de animales, que a veces representan escenas. Pero la vulva, así como las piletas de las que salen canales, no están presentes. ${ }^{6 r} \mathrm{Al}$ norte de $\mathrm{La}$ Candela, a $2 \mathrm{~km}$ de distancia, se ubica una peña no muy alta y ancha, aislada entre los campos y lomeríos, del otro lado del río: el Peñasco de la Cruz. En él hay innumerables vulvas grabadas, así como pocitos de los que salen canales sinuosos que descienden por la roca. No hay cuadriláteros ni motivos antropomorfos o zoomorfos. ${ }^{62}$ Se trata por tanto de dos sitios ubicados en una posición muy cercana al eje norte-sur, que reproducen esa dualidad de mensajes observada en el alto río Ramos; transmiten, pues, mensajes similares. La diferencia más relevante respecto de aquel paisaje es que estos dos conjuntos no están asociados físicamente con sitios provistos de estructuras, habitacionales o de otras funciones, y las vulvas están fuera del espacio doméstico.

En el paisaje chalchihuiteño cercano al cañón de Molino, hacia el sur, también hemos observado esta oposición excluyente entre cuadrilátero y vulva. ${ }^{63}$

El venado aparece en El Olote, aunque no es abundante. Éste es uno de los motivos más característicos del arte rupestre del noroeste de Durango. En otros sitios se encuentra asociado a cuadriláteros. Sin embargo, en el caso del alto río Ramos, sólo aparece en El Olote, asociado a canales, pocitos y vulvas. Se puede decir, por tanto, que participa de la creación del paisaje particular del alto río Ramos, y de esa oposición de mensajes referentes a los dos tipos de fuerzas del universo.

Además de las diferencias que hay en los motivos del arte rupestre de La Tutuveida y El Olote, la ubicación de los conjuntos es diferente. Mientras que en La Tutuveida el conjunto se encuentra alejado de la cumbre del sitio, al pie del cerro, alejado de las estructuras más elaboradas y más relevantes, en un extremo del sitio, junto a unos manantiales de agua caliente, en El Olote el conjunto de arte rupestre ocupa la cima del cerro, alrededor de la cual se hallan las construcciones.

\footnotetext{
61. Forcano, El arte rupestre..., op. cit.

62. Barbot, op. cit.

63. Berrojalbiz et al., op. cit.
} 
178

FERNANDO BERROJALBIZ

\section{El eje norte-sur y las orientaciones astronómicas}

Existen por tanto dos cerros en los extremos del territorio del alto río Ramos que tienen referentes con los niveles celestes del universo y con el inframundo, con ámbitos de lo sagrado y de la vida social y política de la comunidad, que están enmarcando el espacio de la comunidad chalchihuiteña. Estos cerros, además, se encuentran en los extremos de un eje norte-sur, y casi sobre el mismo meridiano (fig. 2). Por tanto, los valores de este eje en la ideología mesoamericana, los valores del norte y del sur, eran importantes para esta comunidad. Para apoyar tal hipótesis me centraré en las orientaciones de los edificios chalchihuiteños.

La Tutuveida es el sitio del valle donde mejor se han conservado las construcciones y donde mejor se puede observar la orientación de los edificios. Se han registrado cuatro orientaciones distintas, cercanas las cuatro al norte astronómico. ${ }^{64}$ Creo que corresponden a otras tantas épocas, en cada una de las cuales se seguía una determinada orientación para construir las estructuras del sitio. Todas ellas de acuerdo con la posición de un conjunto de estrellas que se encontraban en la bóveda celeste dentro de la zona circumpolar, en la franja del cielo situada en la dirección del norte geográfico de la Tierra, y por tanto en la orientación de un eje norte-sur (comunicación personal del astrónomo Daniel Flores). Ese cambio de la orientación se debe al movimiento de precesión de la Tierra, debido al cual ese grupo de estrellas cambia de posición para un observador que se encuentre en el alto río Ramos. Esto quiere decir que, en la época de la ocupación del valle por los chalchihuiteños, éstos veían un grupo de estrellas en el cielo hacia el norte geográfico y, según los cambios de posición de ese grupo de estrellas en el cielo a lo largo del tiempo, los chalchihuiteños cambiaban de orientación los nuevos edificios que iban a construir.

La importancia de esta dirección norte-sur y la ubicación de los dos cerros más relevantes en los extremos de ese eje refuerza la idea de una dualidad en el simbolismo de los dos cerros sagrados, la dualidad característica de la cosmovisión mesoamericana, que se manifestó en un eje norte-sur.

64. Berrojalbiz, op. cit., pp. 523-524, cuadro 8.I. 


\section{El paisaje simbólico}

En el teatro del valle del alto río Ramos se representó el universo en miniatura, y como éste se hallaba compuesto por dos ámbitos, se plasmó esa dualidad en dos cerros situados en el mismo eje, uno al norte y otro al sur, simbolizando un ámbito cada uno de ellos. Algo parecido se había simbolizado en el recinto sagrado de la ciudad de Tenochtitlán, en donde el Templo Mayor representaba el universo con su dualidad, por lo que se habían erigido dos templos, como dos cerros: el norte dedicado al culto de Tláloc, al dominio húmedo y frío; el sur, dedicado a Huitzilopochtli, al dominio ígneo, solar, cálido y seco. ${ }^{65}$

En el caso del alto río Ramos, en vez de representarse esa dualidad en un mismo lugar con dos templos o cerros, se habían separado los dos promontorios, ubicándose en el lugar geográfico que les correspondía dentro del teatro o paisaje que reproducía el universo, a la vista uno del otro.

Esa dualidad separada también refleja la lucha cósmica eterna entre las dos fuerzas del universo, ese combate simbolizado cada vez que se juega a la pelota. En la cultura chalchihuiteña, ese enfrentamiento sin final entre las dos esferas de la naturaleza había sido el tema de varias representaciones, como las que se observan en las copas decoradas al pseudo-cloisonné halladas en el sitio de Alta Vista. En ellas se aprecia cómo un águila, la parte solar y celeste, ha capturado en su pico a una serpiente, la parte terrestre y del inframundo. ${ }^{66}$

En otros territorios de la cultura chalchihuiteña se había representado en el paisaje, de distinta forma, esta lucha cósmica, esta concepción dual del universo. Es el caso del territorio adyacente del pueblo de Presidios en la cuenca del río Tepehuanes, como ya se ha explicado.

En el alto río Ramos, la lucha cósmica se representó mediante el paisaje, creado expresamente para simbolizar el relato correspondiente a ella.

Para comprender la construcción de ese paisaje simbólico, hay que tener en cuenta que los chalchihuiteños llegaron a estas tierras en un movimiento migratorio. Como refiere López Austin, "La toma de posesión de un territorio implica la extensión en él de distintas manifestaciones de la fuerza divina”. ${ }^{67} \mathrm{Al}$ llegar a

65. Broda, “Cosmovisión y observación...”, op. cit., p. 422.

66. Thomas Holien y Robert B. Pickering, "Analogues in Classic Period Chalchihuites Culture to Late Mesoamerican Ceremonialism", en E. Pastory (comp.), Middle Classic Mesoamerica: AD 400-700, Nueva York, Columbia University Press, 1978.

67. López Austin, op. cit., p. 217. 
este paraje, para apropiarse de este territorio, tuvieron que resignificar todo el espacio, llenarlo de su cosmovisión, de su simbolismo, debieron vincularlo con sus dioses, su origen y sus ancestros, y construir un paisaje simbólico original.

El paisaje del alto río Ramos: ¿elementos precursores

de los paisajes simbólicos del centro de México en el Posclásico final?

A lo largo de este trabajo se han visto similitudes notables entre la información de los paisajes simbólicos y rituales del centro de México para el Posclásico final, sobre todo de los mexicas, y lo que he encontrado en el valle del alto río Ramos. Uno de los ámbitos en donde se destacan más tales semejanzas es el culto a los cerros. En El Olote, los grabados transmiten mensajes similares a los del culto a Tláloc en los cerros del centro de México, y a la concepción de estos cerros como el lugar donde se guardan todos los mantenimientos. En La Tutuveida, el otro cerro de relevancia simbólica, unos manantiales de agua caliente refuerzan la idea del cerro como sitio lleno de agua.

También llaman la atención las semejanzas en la humanización de estos cerros. En los dos casos del alto río Ramos existen construcciones especiales en la cima, asociadas a afloramientos rocosos vistosos (en el caso de La Tutuveida, al pie del cerro, no en la cima, por la presencia del agua caliente), en donde se grabaron petroglifos y pocitas, como se indica respecto a la cuenca de México en las postrimerías de la época prehispánica. Además, incluso se han encontrado, en estas dos elevaciones del alto río Ramos, esculturas de forma parecida a las asociadas al culto a los cerros en el centro, destacando la hallada en La Tutuveida, con un recipiente en la cabeza donde hay restos de sustancias quemadas.

Por otra parte, no es de extrañar que encontremos expresada en el paisaje simbólico del alto río Ramos la concepción dual del universo, tan inherente a la tradición mesoamericana. Lo que sorprende es la atención, la forma de representarla tan explícitamente y de modo tan similar a las culturas del centro de México en vísperas de la conquista. Esta similitud se nota de manera especial en la comparación de este paisaje, que es una representación del universo y la concepción dual de éste expresada geográficamente en un territorio, con el rico simbolismo creado en el Templo Mayor para representar también el universo con su división holística en dos ámbitos.

Todo lo anterior confirma y refuerza la teoría de que los chalchihuiteños llegaron en una migración desde el centro de México, portando una tradición que se había engendrado allí y que fueron desarrollando en sus tierras norteñas. Después de su epopeya septentrional, parte importante de los chalchihuiteños 
regresó al sur y participó en la creación de Tula y en la conformación del simbolismo religioso del centro de México en el Posclásico. ${ }^{68}$ Es lógico pensar que estas ideas se transmitieron junto con los aportes procedentes del norte que ya había señalado Hers, como la sala claustro, el chac-mool y el tzompantli. No quiero decir que lo hallado en el norte de Durango sean los antecedentes directos de los elementos del centro de México, que los aspectos que conformaron los paisajes simbólicos, por ejemplo, de los mexicas llegaron directa y exclusivamente desde Durango. Pero subrayo que esta información, de la cual forman parte las ideas de este trabajo, es una vía muy importante de investigación y de comprensión de las culturas del centro de México en el Posclásico que ya no se puede soslayar.

Este paisaje plenamente mesoamericano en los confines septentrionales pervivió en cierta forma e influyó en los paisajes que se crearon después, como en el que construyeron los tepehuanes, quienes llegaron poco después del abandono chalchihuiteño, con una tradición norteña diferente. No obstante, reconocieron los espacios sagrados mesoamericanos y los asimilaron a sus concepciones, así como las esculturas en piedra. ${ }^{69}$ Los elementos simbólicos chalchihuiteños se mezclaron con los de los tepehuanes, dando lugar a un paisaje nuevo y original. $\$$

68. Hers, Los toltecas..., op. cit.

69. Berrojalbiz, op. cit.

N.B. Las investigaciones en que se basa este artículo fueron apoyadas mediante un contrato del Instituto de Investigaciones Estéticas de la Universidad Nacional Autónoma de México (200I) con el Consejo Nacional de Ciencia y Tecnología (Conacyt, proyecto U406II-S) y el Programa de Apoyo a Proyectos de Investigación e Innovación Tecnológica de la Universidad Nacional Autónoma de México (PAPIIT, proyecto IN 308602). 